\title{
A China na cadeia têxtil - vestuário: impactos após a abertura do comércio brasileiro ao mercado mundial e do final dos Acordos Multifibras (AMV) e Têxtil Vestuário (ATV)
}

\author{
Achyles Barcelos da Costa* \\ Nelton Carlos Conte** \\ Valquiria Carbonera Conte ${ }^{* * * *}$
}

\section{Resumo}

Setores intensivos em mão de obra no Brasil, como os de calçados, de móveis e de confecções, passam por fortes pressões concorrenciais, em consequência da presença, em seus mercados de atuação, de competidores asiáticos com ambiente produtivo mais favorável à competitividade. Este estudo teve por objetivo investigar a participação da China no mercado têxtil-vestuário mundial e nas relações comerciais com Brasil no período de 1990 a 2009, movida pelo final dos acordos comerciais AMF e ATV. A base informacional do estudo é composta de dados provenientes de instituições nacionais e internacionais. O que se observa é que a presença da China no mercado internacional têxtil-vestuário aumentou, colocando esse país como o principal exportador mundial. Com relação ao mercado brasileiro, ficou demonstrado que, na indústria têxtil e do vestuário, os principais impactos foram a redução de mão de obra empregada e o aumento das importações.

Palavras-chave: Cadeia têxtil-vestuário. Mercado chinês. Estratégia competitiva. Acordos comerciais.

Economista. Doutor em Economia. Professor convidado da Universidade Federal do Rio Grande do Sul (UFRGS).E-mail: achyles.bc@ufrgs.br

*** Contador. Mestre em Desenvolvimento Regional pela Unisc. Professor da Faculdade de Ciências Econômicas, Administrativas e Contábeis da UPF. E-mail: conte@upf.br

*** Administradora. Mestra em Administração pela Unisinos. E-mail: valquiriaconte@hotmail.com

http://dx.doi.org/10.5335/rtee.v0i40.3442

Submissão: 28/11/2012. Aceite: 03/01/2013 


\section{Introdução}

O presente estudo investiga a participação da China na cadeia têxtil - vestuário mundial e brasileira, no período de 1990 a 2009. No caso do Brasil, o objetivo é investigar os impactos produzidos nas relações comerciais com esse país, depois da abertura do comércio brasileiro ao mercado mundial, principalmente após o final dos acordos comerciais.

A cadeia produtiva têxtil-vestuário é parte integrante do complexo têxtil. Suas atividades reúnem desde o beneficiamento de fibras naturais até a confecção de roupas, formando uma cadeia relativamente linear. O resultado de uma etapa é o principal insumo da etapa seguinte, independentemente de fatores como sequência e tecnologia de produção. São os segmentos finais (tecidos, roupas, acessórios e demais confeccionados têxteis) que conferem dinamismo à cadeia produtiva como um todo, estando vinculada ao consumidor final por meio do comércio atacadista ou varejista.

As empresas da cadeia têxtil-vestuário estão passando, desde a última metade dos anos 1990, no Brasil, por inúmeras transformações, principalmente após a abertura do mercado e o fim dos acordos têxteis, que regulavam esse setor até 2005. Antes da abertura do mercado, as empresas tinham suas estratégias voltadas aos preços dos produtos e à demanda interna. Uma reduzida quantidade de empresas produtoras de fios e tecidos exportava para alguns países, mas os produtos possuíam baixo custo e eram semimanufaturados. A cadeia possuía reduzida tecnologia, ou seja, elevada quantidade de máquinas antigas e modelos de gestão superados, sem contar que a mão de obra empregada era pouco qualificada. Com a competição em nível global, para poderem competir e sobreviver no mercado, essas organizações adotaram novos modelos de gestão, obrigando-se a modernizar seu parque fabril, bem como a qualificar os trabalhadores e a mudar suas estratégias.

Assim, a cadeia têxtil-vestuário passou por diversas modificações com a abertura comercial, mas outros dois fatores influenciaram diretamente essa indústria. O Acordo Multifibras (AMF) - 1974 a 1994 - estabelecia quotas sobre as exportações de países em desenvolvimento para países desenvolvidos e o Acordo sobre Têxteis e Vestuário (ATV) - 1995 a 2004 - tinha como objetivo eliminar, gradativamente, o sistema de quotas impostas aos países em desenvolvimento e integrar o comércio de artigos têxteis às regras da Organização Mundial do Comércio (OMC). Assim, em 2005, passou a vigorar a liberalização no comércio mundial do setor têxtil. 
Com a exposição do Brasil à concorrência internacional, a cadeia têxtil-vestuário perdeu participação no mercado, devido a deficiências em capacitação tecnológica e gerencial e ao reduzido desempenho comercial da cadeia. Para competir no mercado, o parque fabril foi sendo atualizado por meio da importação de máquinas e equipamentos. Matérias-primas como fibras, que antes da abertura comercial eram utilizadas em sua maioria naturais, passaram a ser artificiais e sintéticas ou a ser misturadas. Os principais filamentos sintéticos e artificiais foram sendo adquiridos no mercado externo, principalmente da China.

Assim, cada região do Brasil, na cadeia têxtil-vestuário, buscou se ajustar diante dos padrões competitivos proporcionados pela abertura do mercado. Dentre os estados, os mais expressivos da cadeia têxtil-vestuário são: Rio de Janeiro, São Paulo, Goiás, Mato Grosso, Ceará, Paraná, Santa Catarina e Rio Grande do Sul. O Rio de Janeiro possui um polo importante de confecção; São Paulo tem como destaque o elo da tecelagem; Goiás, Mato Grosso e Paraná abastecem vários outros estados com a fibra de algodão; Santa Catarina é a principal confeccionista nas linhas de cama, mesa e banho, além da malharia; o Ceará possui, na cidade de Fortaleza, um expressivo parque de fiação, tecelagem, malharia e confecção; e, finalmente, o Rio Grande do Sul tem como característica principal a fiação, tecelagem, malharia e confecção da fibra natural lã.

A partir dos anos 2000, pôde-se verificar uma elevada quantidade de produtos têxteis chineses no Brasil. Esses produtos iam desde filamentos até os confeccionados (cama, mesa, banho, malhas, confeccionados em geral). Os produtos oriundos da China trouxeram inúmeros problemas à cadeia têxtil-vestuário, em especial à tecelagem e ao vestuário, traduzidos em perda da competitividade, redução da quantidade de pessoal empregado, fechamento de empresas, aumento da informalidade, resultando em sonegação trabalhista e fiscal, entre outros fatores.

Diante do exposto, o problema que este estudo pretende responder é: quais os impactos na cadeia produtiva têxtil-vestuário do Brasil após a abertura do comércio brasileiro ao mercado mundial, principalmente em relação à indústria chinesa? Com o intuito de responder a esse questionamento, o método de pesquisa envolveu duas fases quantitativas. Além dessas fases, procurou-se proceder a uma retomada de conceitos teóricos relacionados ao tema, o que permitiu a construção de uma base teórica vinculando as questões abordadas na realidade da competitividade empresarial e da cadeia têxtil-vestuário.

$\mathrm{Na}$ primeira fase, quantitativa, fez-se o levantamento de informações sobre a cadeia têxtil-vestuário, com base em dados de organismos internacionais e nacionais. Inicialmente, foi investigada a participação da China no mercado 
têxtil-vestuário mundial entre 1990 e 2009, utilizando dados de organismos internacionais (Comtrade), onde foram analisados os capítulos 50 a 63 da Nomenclatura Comum do Mercosul (NCM) (Apêndice C), que englobam a cadeia desde os fios e filamentos até as confecções. Posteriormente, recorrendo a dados nacionais no MTE/RAIS, caracterizou-se a indústria têxtil e de vestuário no Brasil, bem como sua participação no mercado internacional através de informações contidas do MDIC/Alice, no período de 1990 a 2010.

\section{A China no comércio internacional da cadeia têxtil-vestuário}

A globalização tem alterado a dinâmica de nações, de empresas e de indústrias, refletindo em mudanças dos padrões de comércio internacional, em que novos players vêm se destacando nos mercados, particularmente os de origem asiática.

A participação da China no comércio mundial ao longo dos anos tem aumentado nos mais variados setores da indústria, particularmente nos intensivos em mão de obra, como os da cadeia têxtil-vestuário. No caso dessa cadeia, tal presença pode ser observada desde antes do fim dos AMFs e do acordo relacionado a têxteis e vestuário.

O AMF, negociado em 1974, esteve em vigência até 1993. O acordo objetivava o aumento do escopo de regulação e a provisão de uma estrutura de regras e procedimentos nos quais os países desenvolvidos poderiam impor restrições, protegendo, dessa forma, o emprego de suas indústrias produtoras de têxtil e de vestuário (WOHN, 2001). Seus efeitos sobre o comércio mundial em produtos têxteis e roupas foram intensos, pois o AMF limitou a taxa de crescimento das exportações dos países em desenvolvimento e beneficiou países desenvolvidos, como os Estados Unidos, com um aumento de penetração nos mercados europeus. Contudo, no início dos anos 1980, os produtores europeus aumentaram, consideravelmente, sua penetração no mercado norte-americano (DICKEN, 2009). Para contornar as restrições definidas pelo aumento das limitações de exportação, os países em desenvolvimento buscaram diversas soluções, segundo Dicken (2009, p. 285):

a) Um país produtor que tivesse alcançado o teto de sua quota em um produto alternaria para outro item.

b) Era utilizada etiquetagem falsa para mudar o suposto país de origem (um ato ilegal).

c) As empresas realocavam uma parte de sua produção em países que não eram signatários do AMF, ou cuja quota não tinha sido totalmente usada pelos produtores domésticos. 
Devido a essas práticas, setores inteiros de vestuário de alguns países em desenvolvimento foram, efetivamente, criados em decorrência de quotas estipuladas pelo AMF. Contudo, a Rodada do Uruguai, ao final da década de 1980, indicou que as sucessivas prorrogações do AMF haviam se tornado complexas e sem qualquer solução que atendesse às disputas estabelecidas.

Em 1995, a regulamentação do comércio em produtos têxteis e roupas foi incorporada à OMC. O acordo garantia um período de transição (1995-2004) para um mercado livre, com redução gradual de barreiras comerciais e com a sua extinção total em janeiro de 2005 (SEYOUM, 2007). Nesse ínterim, os países desenvolvidos (Estados Unidos e União Europeia) definiram procedimentos de monitoramento e negociaram novas quotas de importação com a China para continuarem em vigor até 2008. O fim desse acordo favoreceu os mercados chinês e indiano, mais competitivos em têxteis.

Historicamente, a presença mais ativa da indústria de têxteis e vestuário na China inicia-se a partir da década de 1960. Ao ser criada a República Popular da China (RPC), em 1949, quase não existia indústria de vestuário no país. Em 1978, ano que marcou o início da "política de portas abertas", já se registrava, na China, uma produção de 673 milhões de peças confeccionadas em vestuário, produção que passou a crescer de forma bastante expressiva, chegando a 17,5 bilhões de peças em 2000 (SENAI; CETIQT; IPTM, 2004). Na Tabela 1, pode-se verificar esse crescimento.

Tabela 1: Produção da indústria de confecção na China (1980/2000

\begin{tabular}{|c|c|}
\hline & Produção \\
\cline { 2 - 2 } Ano & (em bilhões de peças) \\
\hline 1980 & 1,0 \\
\hline 1985 & 1,3 \\
\hline 1990 & 3,2 \\
\hline 1995 & 9,7 \\
\hline 2000 & 17,5 \\
\hline
\end{tabular}

Fonte: adaptado de CNTIC/IPTM (2004).

Na indústria têxtil, a China destaca-se pela produção de tecidos em fios sintéticos e artificiais, além do uso de fibras naturais como o algodão para a fabricação de tecidos em malha. 
Além da malha manufaturada, a produção e o consumo de fibra de poliéster pela China, em 2009, alcançou 10,93 milhões de toneladas/ano, representando 81,6\% do total produzido na Ásia, segundo dados da China Chemical Repórter (2011). Dos fios e fibras consumidos, foram elaborados 11,7 bilhões de peças em tecido de malha e 12,2 bilhões de peças produzidas em tecido plano, além da produção de meias, que atingiu a quantidade de 11,5 bilhões de pares em 2002 (SENAI; CETIQT; IPTM, 2004).

A cadeia têxtil-vestuário da China vem mostrando crescente participação no mercado internacional por meio das exportações de seus produtos (fios, tecidos e vestuário em geral), sob influência do estímulo do Governo Chinês ${ }^{1}$ e, principalmente, pelo seu baixo custo de produção. De acordo com a tabela 2 , o custo de produção da China, relativo a nove categorias de produtos têxteis, posiciona o país como o mais competitivo em sete delas, quando comparado a outros produtores internacionais como Brasil, Índia, Coreia, Turquia e EUA. Já o Brasil é mais competitivo em três categorias (em uma delas, junto com a China).

Tabela 2: Ranking de menor custo de produção em segentos da cadeia têxtil da China e do Brasil em relação a outros produtores internacionais - 2013

\begin{tabular}{|l|c|r|r|r|r}
\hline & \multirow{2}{*}{ Produto } & \multicolumn{2}{|c|}{ China } & \multicolumn{2}{c}{ Brasil } \\
\cline { 3 - 6 } & Unidade & \multicolumn{1}{c|}{ Custo } & Posição & Custo & Posição \\
\hline Fio de filatório de anel & US\$/kg & 1,08 & $1^{\circ}$ & 1,31 & $4^{\circ}$ \\
\hline Fio Open End (OE) & $"$ & 0,83 & $1^{\circ}$ & 1,01 & $4^{\circ}$ \\
\hline Fio Texturizado & $"$ & 0,31 & $1^{\circ}$ & 0,42 & $4^{\circ}$ \\
\hline Tecido plano (fio anel) & US\$/jd & 0,22 & $2^{\circ}$ & 0,20 & $1^{\circ}$ \\
\hline Tecido plano (fio OE) & $"$ & 0,22 & $2^{\circ}$ & 0,20 & $1^{\circ}$ \\
\hline Tecido plano (fio texturizado) & $"$ & 0,37 & $1^{\circ}$ & 0,37 & $1^{\circ}$ \\
\hline Malha (fio anel) & $"$ & 0,08 & $1^{\circ}$ & 0,14 & $5^{\circ}$ \\
\hline Malha (fio OE) & $"$ & 0,04 & $1^{\circ}$ & 0,07 & $5^{\circ}$ \\
\hline Malha (fio texturizado) & $"$ & 0,04 & $1^{\circ}$ & 0,06 & $5^{\circ}$ \\
\hline
\end{tabular}

Fonte: adaptado de IMTF. Cost Comparison (2003) apud CNTIC/IPTM (2004).

Com o intuito de observar a participação da China no comércio internacional na cadeia têxtil-vestuário, inicia-se a análise pelo primeiro elo da cadeia, composto por fibras naturais e filamentos químicos. Na Tabela 3, estão relacionadas as exportações mundiais desses fios (Capítulos 50 [seda], 51 [lã], 53 [algodão] 54 e 55 [filamentos químicos] da NCM) e a participação das exportações da China, respectivamente. 
Tabela 3: Exportações mundiais de fibras naturais e de filamentos químicos - 1990/2009

\begin{tabular}{|c|c|c|c|c|c|c|c|c|c|}
\hline & \multicolumn{2}{|c|}{ SEDA } & \multicolumn{2}{|c|}{ LÄ } & \multicolumn{2}{|c|}{ ALGODÃO } & \multicolumn{2}{|c|}{ 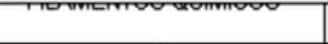 } & \multirow{2}{*}{\begin{tabular}{|c|} 
TOTAL \\
Milhões USS
\end{tabular}} \\
\hline ANO & Milhões USS & $\%$ & $\begin{array}{c}\text { Milhões } \\
\text { USS }\end{array}$ & $\%$ & Milhões USS & $\%$ & Milhões USS & $\%$ & \\
\hline 1990 & 908,0 & 2,6 & $5.443,0$ & 15,5 & $9.253,0$ & 26,5 & $19.354,0$ & 55,4 & $34.958,0$ \\
\hline 1995 & $3.297,0$ & 3,1 & $14.903,0$ & 14,0 & $32.453,0$ & 30,5 & $55.875,0$ & 52,4 & $106.528,0$ \\
\hline 2000 & $2.456,0$ & 2,4 & $11.967,0$ & 11,5 & $32.552,0$ & 31,4 & $56.820,0$ & 54,7 & $103.795,0$ \\
\hline 2005 & $3.203,0$ & 2,5 & $13.114,0$ & 10,4 & $45.251,0$ & 36,1 & $64.189,0$ & 51,0 & $125.757,0$ \\
\hline 2009 & $2.770,0$ & 2,5 & $10.034,0$ & 8,9 & $40.205,0$ & 35,7 & $59.591,0$ & 52,9 & $112.600,0$ \\
\hline
\end{tabular}

Fonte: Comtrade - United Nations Statistics Division (2011). Elaboração própria.

$\left.{ }^{*}\right)$ Filamentos químicos incluem artificiais e sintéticos

Capítulos 50 (seda), 51 (lã), 53 (algodão) 54 e 55 (filamentos químicos) Sistema Harmonizado HS 1992.

Quando se analisa o desempenho da China nas exportações mundiais dessas fibras, observa-se (Tabelas 4 e 5) que esse país é responsável por quase metade das vendas internacionais de seda. Nota-se, ainda, que o mercado chinês recuperou posição na lã de 1995 a 2009 e que a sua participação vem crescendo no comércio de algodão e em filamentos químicos: no primeiro, a sua participação saltou de $9,1 \%$ em 1990 para 23,9 em 2009, enquanto os filamentos tiveram um acréscimo de 5,0\% para $22,7 \%$ das exportações mundiais entre 1990 e 2009.

Tabela 4: Participação da China nas exportaões mundiais de fibras naturais e de filamentos químicos - 1990/2009

\begin{tabular}{|c|c|c|c|c|c|c|c|c|c|c|c|c|}
\hline & \multicolumn{3}{|c|}{ SEDA } & \multicolumn{3}{|c|}{ LÃ } & \multicolumn{3}{|c|}{ ALGODÃO } & \multicolumn{3}{|c|}{ FILAMENTOS QUIMICOS* } \\
\hline ANO & $\begin{array}{c}\text { Mundiais } \\
\text { Milhőes USS }\end{array}$ & \begin{tabular}{c|} 
China \\
Millőes USS
\end{tabular} & $\%$ & $\begin{array}{c}\text { Mundiais } \\
\text { Milhőes USS }\end{array}$ & \begin{tabular}{|c|} 
China \\
Milhőes USS
\end{tabular} & $\%$ & $\begin{array}{c}\text { Mundiais } \\
\text { Milhőes USS }\end{array}$ & \begin{tabular}{|c|} 
China \\
Milhőes USs
\end{tabular} & $\%$ & $\begin{array}{c}\text { Mundiais } \\
\text { Milhões USS }\end{array}$ & \begin{tabular}{|c|} 
China \\
Milhőes USS
\end{tabular} & $\%$ \\
\hline 1990 & 908,0 & 453,0 & 49,9 & $5.443,0$ & 838,0 & 15,4 & $9.253,0$ & 842,0 & 9,1 & $19.354,0$ & 962,0 & 5,0 \\
\hline 1995 & $3.297,0$ & $1.173,0$ & 35,6 & $14.903,0$ & 773,0 & 5,2 & $32.453,0$ & $3.850,0$ & 11,9 & $55.875,0$ & $3.293,0$ & 5,9 \\
\hline 2000 & $2.456,0$ & 928,0 & 37,8 & $11.967,0$ & $1.202,0$ & 10,0 & $32.552,0$ & $3.730,0$ & 11,4 & $56.820,0$ & $4.050,0$ & 7,1 \\
\hline 2005 & $3.203,0$ & $1.336,0$ & 41,7 & $13.114,0$ & $1.845,0$ & 14,1 & $45.251,0$ & $7.438,0$ & 16,4 & $64.189,0$ & $10.277,0$ & 16,0 \\
\hline 2009 & $2.770,0$ & $1.288,0$ & 46,5 & $10.034,0$ & $1.626,0$ & 16,2 & $40.205,0$ & $9.601,0$ & 23,9 & $59.591,0$ & $13.555,0$ & 22,7 \\
\hline
\end{tabular}

Fonte: Comtrade - United Nations Statistics Division (2011). Elaboração própria.

Tabela 5: Principais países exportadores selecionados de fibras naturais de filamentos químicos 2009

\begin{tabular}{|c|c|c|c|c|c|c|c|c|c|c|c|}
\hline \multicolumn{3}{|c|}{ Seda } & \multicolumn{3}{|c|}{ Lã } & \multicolumn{3}{|c|}{ Algodão } & \multicolumn{3}{|c|}{ Filamentos Químicos* } \\
\hline Pais & $\begin{array}{c}\text { Milhões } \\
\text { USS }\end{array}$ & $\%$ & Pais & $\begin{array}{c}\text { Milhões } \\
\text { USS }\end{array}$ & $\%$ & Pais & $\begin{array}{c}\text { Milhões } \\
\text { USS }\end{array}$ & $\%$ & Pais & $\begin{array}{c}\text { Milhões } \\
\text { USS }\end{array}$ & $\%$ \\
\hline China & $1.287,7$ & 46,5 & Itália & $2.018,0$ & 20,1 & China & $9.601,0$ & 23,9 & China & $13.555,0$ & 22,7 \\
\hline Itália & 360,0 & 13,0 & Austrália & $1.452,0$ & 14,5 & Estados Unidos & $4.924,0$ & 12,2 & Alemanha & $3.187,8$ & 5,4 \\
\hline India & 271,1 & 9,8 & China & $1.626,0$ & 16,2 & India & $3.195,0$ & 8.0 & Estados Unidos & $3.041,9$ & 5,1 \\
\hline Japão & 100,7 & 3,6 & Alemanha & 695,1 & 6,9 & Itália & $2.049,0$ & 5,1 & Japão & $3.276,4$ & 5,5 \\
\hline França & 83,1 & 3,0 & Nova Zelândia & 400,9 & 4,0 & Turquia & $1.278,0$ & 3,2 & India & $2.998,1$ & 5,0 \\
\hline Alemanha & 78,4 & 2,8 & Reino Unido & 344,1 & 3,4 & Alemanha & $1.083,0$ & 2,7 & Itália & $2.810,5$ & 4,7 \\
\hline Reino Unido & 50,3 & 1,8 & Japão & 256,6 & 2,6 & Brasil & 844,7 & 2,1 & Turquia & $1.792,7$ & 3,0 \\
\hline Espanha & 41,6 & 1,5 & Turquia & 152,9 & 1,5 & Japão & 666,7 & 1,7 & França & $1.348,7$ & 2,3 \\
\hline Vietnã & 32,4 & 1,2 & França & 151,8 & 1,5 & Espanha & 662,4 & 1,6 & Espanha & $1.047,4$ & 1,8 \\
\hline Estados Unidos & 25,6 & 0,9 & Argentina & 146,9 & 1,5 & França & 607,1 & 1,5 & Reino Unido & 913,7 & 1,5 \\
\hline Outros & 439,1 & 15,9 & Outros & $2.789,7$ & 27,8 & Outros & 15.294 .1 & 38,0 & Outros & 25.618 .8 & 43,0 \\
\hline TOTAI & 27700 & 1000 & ITOTAI & 100340 & 1000 & ITOTAI & 402050 & 1000 & TOTAI & 595910 & 1000 \\
\hline
\end{tabular}

Fonte: Comtrade - United Nations Statistics Division (2011). Elaboração própria.

Nota: (*) Filamentos químiocos incluem artificiais e sintéticos.

Capítulos 50 (seda), 51 (lã), 53 (algodão) 54 e 55 (filamentos químicos) Sistema Harmonizado HS 1992 
Esse desempenho da China fica ainda mais evidente quando comparado com outros players internacionais. Em 2009, o país liderava as exportações mundiais de seda $(46,5 \%)$, de algodão $(23,9 \%)$ e de filamentos químicos $(22,7 \%)$, perdendo apenas na lã, considerando-se que a Itália se destacava como o principal exportador mundial, com $20,1 \%$ do total.

O segundo elo ou segmento da cadeia têxtil-vestuário é representado pela tecelagem ou malharia. Nas Tabelas 6, 7 e 8, é analisada a participação das exportações da China em relação ao total exportado pelo mundo, apresentando-se, além disso, os principais países importadores de tecidos oriundos da China e os players mundiais.

Tabela 6: Exportações mundiais de tecidos especiais, impregnados e de malha - 1990/2009

\begin{tabular}{|c|c|c|c|c|c|c|c|}
\hline & \multicolumn{2}{|c|}{ Tecidos Especiais ${ }^{1}$} & \multicolumn{2}{|c|}{ Tecidos Impregnados $^{2}$} & \multicolumn{2}{|c|}{ Tecidos Malha ${ }^{3}$} & Total \\
\hline ANO & Milhões US\$ & $\%$ & Milhões US\$ & $\%$ & Milhões US\$ & $\%$ & Milhões US\$ \\
\hline 1990 & $2.024,0$ & 29,7 & $2.624,0$ & 38,5 & $2.174,0$ & 31,9 & $6.822,0$ \\
\hline 1995 & $8.255,0$ & 30,0 & $9.704,0$ & 35,3 & $9.535,0$ & 34,7 & $27.494,0$ \\
\hline 2000 & $8.317,0$ & 22,5 & $12.975,0$ & 35,1 & $15.630,0$ & 42,3 & $36.922,0$ \\
\hline 2005 & $11.299,0$ & 23,8 & $16.340,0$ & 34,4 & $19.853,0$ & 41,8 & $47.492,0$ \\
\hline 2009 & $11.307,0$ & 22,3 & $17.690,0$ & 34,9 & $21.745,0$ & 42,8 & $50.742,0$ \\
\hline
\end{tabular}

Fonte: Comtrade - United Nations Statistics Division (2011). Elaboração própria.

Notas: Capítulo 58, 59, 60 - Sistema Harmonizado HS 1992

(1) Capítulo 58: Tecidos especiais; tecidos tufados; rendas; tapeçarias; passamanarias; bordados

(2) Capítulo 59: Tecidos impregnados, revestidos, recobertos ou estratificados; artigos para usos técnicos

(3) Capítulo 60: Tecidos de malha

Os tecidos de malha são os que tiveram maior valor exportado no período 1990-2009. Esse segmento representava $42,8 \%$ do total mundial exportado em 2009, seguido dos tecidos impregnados, com uma participação de $34,9 \%$, e dos tecidos especiais, com $22,3 \%$ do total. Contudo, o tecido de malha foi o que obteve maior dinamismo, passando de 31,9\% em 1990 para 42,8\% em 2009. Já os tecidos especiais tiveram uma queda, passando de $29,7 \%$ em 1990 para $22,3 \%$ em 2009 , assim como os tecidos impregnados, com uma diminuição de 3,6 pontos percentuais no mesmo período. O comportamento das exportações desse segmento mostra-se, em geral, em constante crescimento no período em análise, passando de um total em torno de 6 bilhões em 1990 para cerca de US $\$ 50$ bilhões em 2009 .

Quando se analisa o seu desempenho nas exportações de tecido (Tabela 7), percebe-se que, a partir da metade da década de 2000, a China toma a condição de importante exportadora. 
Tabela 7: Participação da China nas exportações mundiais de tecidos especiais, impregnados e de malha - 1990/2009

\begin{tabular}{|c|c|c|c|c|c|c|c|c|c|}
\hline & \multicolumn{3}{|c|}{ Tecidos Especiais' } & \multicolumn{3}{|c|}{ Tecidos Impregnados ${ }^{2}$} & \multicolumn{3}{|c|}{ Tecidos Malha $^{3}$} \\
\hline ANO & Mundiais & China & $\%$ & Mundiais & China & $\%$ & Mundiais & China & $\%$ \\
\hline 1990 & $2.024,0$ & 265,0 & 13,1 & $2.624,0$ & 240,0 & 9,1 & $2.174,0$ & 998,0 & 45,9 \\
\hline 1995 & $8.255,0$ & 544,0 & 6,6 & $9.704,0$ & 298,0 & 3,1 & $9.535,0$ & 907,0 & 9,5 \\
\hline 2000 & $8.317,0$ & 742,0 & 8,9 & $12.975,0$ & 396,0 & 3,0 & $15.630,0$ & $1.288,0$ & 8,2 \\
\hline 2005 & $11.299,0$ & $2.709,0$ & 24,0 & $16.340,0$ & $1.755,0$ & 10,7 & $19.853,0$ & $3.652,0$ & 23,4 \\
\hline 2009 & $11.307,0$ & $3.530,0$ & 31,2 & $17.690,0$ & $3.965,0$ & 22,4 & $21.745,0$ & $6.422,0$ & 29,5 \\
\hline
\end{tabular}

Fonte: Comtrade - United Nations Statistics Division (2011). Elaboração própria.

Notas:Capitulo 58,59,60 - Sistema Harmonizado HS1992

(1) Capitulo 58:Tecidos especiais; tecidos tufados; rendas; tapeçarias; passamanarias; bordados

(2) Capítulo 59:Tecidos impregnados, revestidos, recobertos ou estratificados; artigos para usos técnicos

(3) Capitulo 60:Tecidos de malha

Fonte: Comtrade - United Nations Statistics Division (2011). Elaboração própria.

A produção de tecidos, assim como a de confecções, envolve fatores que auxiliam a elevada produtividade da China. Sua mão de obra abundante e de baixo custo, em comparação à dos outros países que atuam no mercado de exportação, beneficia-a em sua produtividade.

Além disso, a energia é de baixo custo e o suprimento de matérias-primas e de outros insumos oriundos de uma completa cadeia produtiva produz não somente as matérias-primas primárias (fibras e fios), mas também os tecidos, acessórios, produtos químicos e outros itens importantes. Essa situação se diferencia daquela de muitos concorrentes que não possuem a cadeia produtiva completa e dependem de contínuas importações.

$\mathrm{Na}$ análise das exportações de tecidos (Tabela 8), fica evidenciada a condição de principal exportadora da China, nos três tipos de tecido em 2009, com uma participação de $31,2 \%$ do mercado de tecidos especiais, de $22,4 \%$ do de tecidos impregnados e de $29,5 \%$ do de tecido de malha. 
Tabela 8 - Principais Países Exportadores Selecionados de Tecidos Especiais, Impregnados e de Malha: 2009

\begin{tabular}{|c|c|c|c|c|c|c|c|c|}
\hline \multicolumn{3}{|c|}{ Tecidos Especiais ${ }^{1}$} & \multicolumn{3}{|c|}{ Tecidos Impregnados ${ }^{2}$} & \multicolumn{3}{|c|}{ Tecidos Malhas } \\
\hline Pais & $\begin{array}{c}\text { Milhões } \\
\text { US\$ }\end{array}$ & $\%$ & Pais & $\begin{array}{l}\text { Milhões } \\
\text { USS }\end{array}$ & $\%$ & Pais & $\begin{array}{c}\text { Milhöes } \\
\text { US\$ }\end{array}$ & $\%$ \\
\hline China & $3.529,8$ & 31,2 & China & $3.965,4$ & 22,4 & China & $6.422,5$ & 29,5 \\
\hline Alemanha & 527,8 & 4,7 & Alemanha & $1.901,5$ & 10,7 & Itália & $1.087,1$ & 5,0 \\
\hline Estados Unidos & 473,8 & 4,2 & Estados Unidos & $1.321,8$ & 7,5 & Turguia & 978,9 & 4,5 \\
\hline França & 459,7 & 4,1 & Itália & 862,0 & 4,9 & Estados Unidos & 910,9 & 4,2 \\
\hline Turquia & 439,0 & 3,9 & Japão & 764,7 & 4,3 & Alemanha & 881,1 & 4,0 \\
\hline Itália & 411,4 & 3,6 & Reino Unido & 542,6 & 3,1 & Japão & 614,9 & 2,8 \\
\hline Japão & 228,7 & 2,0 & França & 514,6 & 2,9 & França & 488,5 & 2,3 \\
\hline India & 193,7 & 1,7 & Canadá & 454,9 & $\overline{2,6}$ & Espanha & 249,9 & $\overline{1,2}$ \\
\hline$\overline{\text { Egito }}$ & 180,7 & 1,6 & Espanha & 329,3 & 1,9 & Reino Unido & 164,3 & 0,8 \\
\hline Espanha & 176,8 & 1,6 & Turquia & 249,9 & $\overline{1,4}$ & Índia & 109,3 & 0,5 \\
\hline Outros & $4.685,6$ & 41,4 & Outros & $6.783,3$ & 38,3 & Outros & $9.837,6$ & 45,2 \\
\hline TOTAL & 7,0 & 100,0 & OTAL & 17.690 .0 & 100,0 & ITOTAL & $21.745,0$ & 100 , \\
\hline
\end{tabular}

Fonte: Comtrade - United Nations Statistics Division (2011). Elaboração Própria

Notas:Capitulo 58,59,60 - Sistema Harmonizado HS 1992

(1) Capitulo 58:Tecidos especiais; tecidos tufados; rendas; tapeçarias; passamanarias; bordados

(2) Capitulo 59:Tecidos impregnados, revestidos, recobertos ou estratificados; artigos para usos técnicos

(3)Capitulo 60:Tecidos de malha

Por fim, a confecção representa o terceiro elo da cadeia têxtil-vestuário. Nesse elo, segundo estudo do Senai, Cetiqt e IPTM (2004), a China destaca-se pela elevada e diversificada oferta em termos de especificações e variedades nos produtos. O país pode produzir todos os tipos de têxteis e confecções desde os básicos até os de moda. As firmas chinesas oferecem serviços de maior valor agregado, reagem rapidamente às mudanças da moda e às demandas dos varejistas, atendendo aos padrões de produtos de uma forma mais adequada do que a dos fornecedores de outras partes do mundo. Essa vantagem pode ser vista na indústria de vestuário, em que os países como Estados Unidos, Japão, Alemanha e outros têm buscado produtos para abastecer as redes de varejo.

A Tabela 9 mostra o total de exportações do mundo em vestuário de malha, não malha e outros confeccionados. O vestuário de malha compreende os produtos confeccionados para bebês (inclusive fraldas), adultos (masculino e feminino), roupas íntimas, roupas para esqui, meias e acessórios. $O$ vestuário não malha compreende todos os produtos listados produzidos com qualquer outra matéria têxtil, com exclusão das pastas. Os demais confeccionados compreendem os artigos da linha lar (cama, mesa, banho, cozinha, cortinas, cobertores, mantas), sacos para embalagem, toldos, tendas e velas para embarcações. 
Tabela 9 - Exportações Mundiais de Vestuário em Malha, Vestuário Não Malha e Outros Confeccionados - 1990/2009

\begin{tabular}{|c|c|c|c|c|c|c|c|}
\hline & \multicolumn{2}{|c|}{ Vestuário em Malha ${ }^{1}$} & \multicolumn{2}{|c|}{ Vestuário Não Malha ${ }^{2}$} & \multicolumn{2}{|c|}{ Outros Confeccionados ${ }^{3}$} & Total \\
\hline ANO & Milhões US\$ & $\%$ & Milhões US\$ & $\%$ & Milhões US\$ & $\%$ & Milhões US\$ \\
\hline 1990 & $14.005,0$ & 36,8 & $20.470,0$ & 53,7 & $3.607,0$ & 9,5 & $38.082,0$ \\
\hline 1995 & $55.164,0$ & 36,3 & $83.539,0$ & 54,9 & $13.356,0$ & 8,8 & $152.059,0$ \\
\hline 2000 & $79.332,0$ & 38,5 & $101.721,0$ & 49,3 & $25.208,0$ & 12,2 & $206.261,0$ \\
\hline 2005 & $120.510,0$ & 40,4 & $144.206,0$ & 48,3 & $33.585,0$ & 11,3 & $298.301,0$ \\
\hline 2009 & $148.223,0$ & 43,8 & $148.640,0$ & 49,8 & $41.365,0$ & 12,2 & $338.228,0$ \\
\hline \multicolumn{8}{|c|}{ Fonte: Comtrade - United Nations Statistics Division (2011). Elaboração Própria } \\
\hline \multicolumn{8}{|c|}{ Notas: Capítulo 61, 62 e 63 - Sistema Harmonizado HS 1992} \\
\hline \multicolumn{8}{|c|}{ (1) Capitulo 61: Vestuário e seus acessórios, de malha } \\
\hline \multicolumn{8}{|c|}{ (2) Capitulo 62:Vestuário e seus acessórios, exceto malha } \\
\hline \multicolumn{4}{|c|}{ (3) Capitulo 63: Outros Confeccionados (linha lar) } & & & & \\
\hline
\end{tabular}

As vendas de vestuário não malha, mesmo tendo uma queda de $3,9 \%$ no período, é a que detém a maior participação das exportações mundiais em malha, com $49,8 \%$ do mercado. O vestuário em malha, por sua vez, é o que apresenta o melhor desempenho, com um crescimento de $7 \%$, detendo $43,8 \%$ do mercado mundial. Os outros confeccionados também revelam crescimento no período, de $2,7 \%$, com uma participação de $12,2 \%$ nas exportações mundiais.

Contudo, os confeccionados (linha lar) foram os que obtiveram maior dinamismo, passando de US\$3 bilhões (9,5\%) em 1990 para US $\$ 41$ bilhões $(12,2 \%)$ em 2009. Da mesma forma, o vestuário em malha, com cerca de US $\$ 14$ bilhões $(36,8)$ em 1990, passou para US $\$ 148$ bilhões $(43,8 \%)$ em 2009 .

As baixas barreiras à entrada na manufatura de roupas tornam a atividade acessível a praticamente todo o país, mesmo nos que apresentam baixos níveis de desenvolvimento econômico. A China já é o maior produtor mundial, na frente da Indonésia, da Índia, do Japão, do Vietnã e da Tailândia. Fora da Ásia, a mais alta produção de roupas acontece no México, nos Estados Unidos, no Brasil, nas Américas, na Itália, na Europa Ocidental, na Romênia, na Polônia, no Leste Europeu e na Federação Russa. A Tabela 10 mostra a participação nas exportações mundiais da China.

\begin{tabular}{|c|c|c|c|c|c|c|c|c|c|}
\hline & \multicolumn{3}{|c|}{ Vestuário em Malha ${ }^{1}$} & \multicolumn{3}{|c|}{ Vestuário Não Malha ${ }^{2}$} & \multicolumn{3}{|c|}{ Outros Confeccionados ${ }^{3}$} \\
\hline & $\begin{array}{c}\text { Mundiais } \\
\text { Milhões US\$ }\end{array}$ & $\begin{array}{c}\text { China } \\
\text { Milhões US\$ }\end{array}$ & $\%$ & $\begin{array}{c}\text { Mundiais } \\
\text { Milhões US\$ }\end{array}$ & $\begin{array}{c}\text { China } \\
\text { Milhões US\$ }\end{array}$ & $\%$ & $\begin{array}{c}\text { Mundiais } \\
\text { Milhões US\$ }\end{array}$ & $\begin{array}{c}\text { China } \\
\text { Milhões US\$ }\end{array}$ & $\%$ \\
\hline 1990 & $14.005,0$ & 183,0 & 1,3 & $20.470,0$ & 193,0 & 0,9 & $3.607,0$ & 273,0 & 7,6 \\
\hline 1995 & $55.164,0$ & $6.937,0$ & 12,6 & $83.539,0$ & $14.345,0$ & 17,2 & $13.356,0$ & $2.562,0$ & 19,2 \\
\hline 2000 & $79.332,0$ & $13.424,0$ & 16,9 & $101.721,0$ & $18.865,0$ & 18,5 & $25.208,0$ & $3.452,0$ & 13,7 \\
\hline 2005 & $120.510,0$ & $30.871,0$ & 25,6 & $144.206,0$ & $35.031,0$ & 24,3 & $33.585,0$ & $10.336,0$ & 30,8 \\
\hline 2009 & $148.223,0$ & $53.763,0$ & 36,3 & $148.640,0$ & $46.716,0$ & 31,4 & $41.365,0$ & $16.817,0$ & 40,7 \\
\hline
\end{tabular}

Fonte: Comtrade - United Nations Statistics Division (2011). Elaboração própria.

Notas:Capitulo 61, 62 e 63 - Sistema Harmonizado HS 1992

(1) Capitulo 61: Vestuário e seus acessórios, de malha

(2) Capítulo 62:Vestuário e seus acessórios, exceto malha

(3) Capitulo 63: Outros Confeccionados (linha lar) 
A China apresenta um dinamismo ao longo do período. Suas exportações, nos segmentos de vestuário em malha e não malha, de 1990 para 2009, mostram, respectivamente, um crescimento de 35 e de 30,5 pontos percentuais. Em relação ao segmento de outros confeccionados, mesmo com oscilações no período, o mesmo país apresentou um crescimento de 33,1 pontos, passando de 7,6\% em 1990 para 40,7\% em 2009.

De acordo com Dicken (2009), tem ocorrido uma grande mudança global na indústria do vestuário, mudança marcada por um distanciamento dos produtores já estabelecidos há muito tempo em direção a novos produtores em desenvolvimento, principalmente Ásia, México e Leste Europeu. O domínio da Ásia, sobretudo da China, como fonte de exportação de roupas fica evidente na Tabela 11.

Tabela 11 - Principais Países Exportadores Selecionados de Vestuário de Malha,Vestuário Não Malha e Outros Confeccionados: 2009

\begin{tabular}{|c|c|c|c|c|c|c|c|c|}
\hline \multicolumn{3}{|c|}{ Vestuário em Malha' } & \multicolumn{3}{|c|}{ Vestuário Não Malha ${ }^{2}$} & \multicolumn{3}{|c|}{ Outros Confeccionados ${ }^{8}$} \\
\hline País & $\begin{array}{c}\text { Milhões } \\
\text { USS }\end{array}$ & $\%$ & País & $\begin{array}{c}\text { Milhões } \\
\text { USS }\end{array}$ & $\%$ & País & $\begin{array}{c}\text { Milhões } \\
\text { USS }\end{array}$ & $\%$ \\
\hline China & $53.763,0$ & 36,3 & China & $46.716,0$ & 31,4 & China & $16.817,0$ & 40,7 \\
\hline Itália & $7.049,0$ & 4,8 & Itália & $11.144,0$ & 7,5 & India & $2.319,0$ & 5,6 \\
\hline Turquia & $6.927,0$ & 4,7 & Alemanha & $8.647,0$ & 5,8 & Alemanha & $2.008,0$ & 4,8 \\
\hline Alemanha & $6.859,0$ & 4,6 & India & $6.125,0$ & 4,1 & Turquia & $1.648,0$ & 4,0 \\
\hline India & $5.187,0$ & 3,5 & França & $5.433,0$ & 3,7 & Estados Unidos & $1.485,0$ & 3,6 \\
\hline França & $3.884,0$ & 2,6 & Turquia & $4.295,0$ & 2,9 & Reino Unido & 814,0 & 2,0 \\
\hline Espanha & $3.593,0$ & 2,4 & Espanha & $3.753,0$ & 2,5 & França & 744,0 & 1,8 \\
\hline Reino Unido & $2.183,0$ & 1,5 & Reino Unido & $2.726,0$ & 1,8 & Itália & 667,0 & 1,6 \\
\hline Estados Unidos & $1.953,0$ & 1,3 & México & $2.455,0$ & 1,6 & México & 664,0 & 1,6 \\
\hline Portugal & $1.818,0$ & 1,2 & Estados Unidos & $1.546,0$ & 1,2 & Portugal & 580,0 & 1,4 \\
\hline Outros & $55.007,0$ & 37,1 & Outros & $55.800,0$ & 37,5 & Outros & $13.619,0$ & 32,9 \\
\hline TOTAL & $148.223,0$ & 100,0 & TOTAL & $148.640,0$ & 100,0 & TOTAL & $41.365,0$ & 100,0 \\
\hline \multicolumn{9}{|c|}{ Fonte: Comtrade - United Nations Statistics Division (2011). Elaboração Própria } \\
\hline \multicolumn{9}{|c|}{ Notas: Capitulo 61, 62 e 63 - Sistema Harmonizado HS 1992} \\
\hline \multicolumn{9}{|c|}{ (1) Capitulo 61: Vestuário e seus acessórios, de malha } \\
\hline \multicolumn{9}{|c|}{ (2) Capitulo 62:Vestuário e seus acessórios, exceto malha } \\
\hline \multicolumn{4}{|c|}{ (3) Capitulo 63: Outros Confeccionados (linha lar) } & & & & & \\
\hline
\end{tabular}

A China aparece como principal exportadora mundial de vestuário, nos três segmentos, com uma participação em torno de $36 \%$. O comportamento das exportações mostra que a China é o principal exportador no segmento de outros confeccionados com exportações de US $\$ 16,8$ bilhões (40,7\%), seguido da Índia, com US $\$$ 2,3 bilhões $(5,6 \%)$, e da Alemanha, com US $\$ 2$ bilhões $(4,8 \%)$ do total exportado pelo mundo. $\mathrm{O}$ vestuário em malha é o segundo segmento em que a China ocupa a primeira colocação, com cerca de US\$ 53,7 bilhões exportados em 2009 (36,3\%), seguido da Itália, com US $\$ 7$ bilhões (4,8\%), e da Turquia, com US\$ 6,9 bilhões $(4,7 \%)$. China $(31,4 \%)$, Itália $(7,5 \%)$ e Alemanha $(5,8 \%)$ foram os países que mais exportaram no segmento de vestuário em não malha. 
No setor do vestuário, o circuito de produção tem sido cada vez mais dominado pelas políticas de compra das grandes cadeias de varejo. A isso se deve a participação intensa dos Estados Unidos, do Japão e da Alemanha como os principais importadores da China. Os maiores varejistas são:

- Estados Unidos: Wal-Mart, Sears, J.C. Penney, Dayton Hudson;

- Japão: Daiei, Mitsukoshi, Daimaru e Ito Yokado;

- Alemanha: Karstadt, Kaufthof, Schickendanz;

- Holanda: C\&A;

- França: Carrefour;

- Grã-Bretanha: Marks and Spencer e Tesco.

$\mathrm{O}$ fato de a China mostrar maior participação em relação aos demais países tem implicações no poder de compra altamente concentrado nas grandes cadeias de varejo. Quando o mercado era dominado pelos varejistas do mercado de massa, a demanda era direcionada para os longos ciclos de produção de roupas padronizadas a baixo custo. À medida que o mercado ficou mais diferenciado e as mudanças na moda tornaram-se mais frequentes, os fabricantes viram-se forçados a reagir de forma mais ágil às demandas do varejo. Assim, a China, como descrito anteriormente, configura-se como um fornecedor em potencial, pois o tempo para $o$ atendimento dos pedidos é tão importante quanto o custo oferecido por esse país na produção de manufaturados (DICKEN, 2009).

Para ajustar-se às características presentes no mercado, países como Estados Unidos, Japão e alguns da Europa buscaram estratégias para enfrentar a concorrência. De modo geral, as empresas pertencentes a esses países mudaram suas estratégias relativas a novas tecnologias na manufatura e nos sistemas gerenciais, bem como a novos relacionamentos entre fornecedores e clientes. As principais, segundo Gereffi (2001), Seyom (2007) e Dicken (2009), são as seguintes:

- especialização em marketing de nichos, visando a enfrentar os baixos preços dos produtos importados;

- inovação e criatividade no desenvolvimento de produtos;

- customização de massa, buscando melhorar a diferenciação dos manufaturados;

- redes de cadeia de suprimentos e sourcing global, visando a uma produtividade maior em termos de custo;

- uso da modalidade "full package" - pacote completo, estratégia de diferenciação já implementada na China, assegurando o sourcing nas fábricas chinesas para o fornecimento de roupas prontas. 
As estratégias adotadas pelos produtores da cadeia têxtil-vestuário são "extremamente complexas e diversificadas". As combinações de inovação tecnológica, diferentes tipos de estratégias de internacionalização e o relacionamento com os varejistas formam uma combinação necessária para gerar um mapa global de produção e comércio mais complexo do que a simples explicação baseada nas diferenças de custos de mão de obra, fator característico da China.

\section{Configuração do Brasil no comércio internacional da cadeia têxtil-vestuário}

O processo de abertura comercial no Brasil, no início da década de 1990, marcou, de forma significativa, o setor têxtil e de confecções. As empresas que antes eram protegidas da concorrência externa passaram a competir com outros mercados, principalmente o Asiático. Outro fator relevante foi o fim do regime de restrições quantitativas, em 2006, as quais eram estabelecidas pelo ATV. Com o término do acordo, houve um acirramento da concorrência e uma redução no número de países que buscavam atingir os mercados de maior poder aquisitivo. As empresas brasileiras da cadeia têxtil-vestuário passaram a ajustar-se a essa situação, alterando suas estratégias para competir no mercado, que estava se tornando mais globalizado.

De modo geral, as indústrias têxtil e de confecção mundiais são compostas por quatro segmentos de produção:

a) preparação de fibras e filamentos (naturais e químicas);

b) preparação de manufaturados têxteis (fiação, tecelagem, malharia e beneficiamento);

c) confecção (vestuário, linha lar e técnicos); e

d) atividades dos canais de distribuição (varejo, atacado etc.).

Nesta seção, será analisada a participação do Brasil no elo da cadeia têxtil-vestuário, com ênfase às relações comerciais com a China, examinando os três segmentos de produção, que englobam da preparação das fibras à confecção.

Uma característica relevante do setor têxtil brasileiro é uma segmentação vertical em empresas independentes nos elos de fiação e tecelagem, de fiação e malharia e de tecelagem e confecção. Existe, também, um reduzido número de empresas que possuem todos esses elos da cadeia integrados verticalmente em uma única planta. A distribuição em território brasileiro dos estabelecimentos no primeiro elo da cadeia têxtil-vestuário, representado pela fiação, pode ser vista na Tabela 12. 
Tabela 12 - Estabelecimentos por Região do Brasil no Elo de Fiação: 2010

\begin{tabular}{|c|c|c|c|c|c|c|c|}
\hline Região & $\begin{array}{c}\text { Fibras } \\
\text { Algodão }^{1}\end{array}$ & $\%$ & $\begin{array}{c}\text { Fibras Naturais, } \\
\text { não algodão }\end{array}$ & $\%$ & $\begin{array}{r}\text { Filamentos } \\
\text { Químicos }\end{array}$ & $\%$ & Total \\
\hline Centro-Oeste & 88 & 18,6 & 3 & 1,4 & 0 & 0 & 91 \\
\hline Nordeste & 140 & 29,6 & 67 & 32,4 & 22 & 14,8 & 229 \\
\hline Norte & 0 & 0 & 14 & 6,8 & 0 & 0 & 14 \\
\hline Sudeste & 154 & 32,6 & 75 & 36,2 & 97 & 65,1 & 326 \\
\hline Sul & 91 & 19,2 & 48 & 23,2 & 30 & 20,1 & 169 \\
\hline Total & 473 & 100 & 207 & 100 & 149 & 100 & 829 \\
\hline
\end{tabular}

Fonte: MTE/RAIS (2011). Elaboração própria.

Notas: Classe 13111, 13120,13138 - CNAE 20 - versão 2.0

(1) Classe 13111: Preparação e fiação de fibras de algodão

(2) Classe 13120: Preparação e fiação de fibras têxteis naturais, exceto algodão

(3) Classe 13138: Fiação de fibras artificiais e sintéticas

Em 2010, existiam no Brasil 829 empresas de fiação, distribuídas pelas cinco regiões do país. As fiações que utilizam o algodão como principal fibra processada somam cerca de 473 empresas, representando $57,1 \%$ do total de estabelecimentos que processam as fibras. Dessas, $32,6 \%$ estão na região Sudeste, tendo como principais estados produtores São Paulo e Minas Gerais, seguidos pela região Nordeste, com 29,6\% das fiações, tendo na Bahia e no Ceará os seus maiores produtores. Os estabelecimentos que processam fibras naturais, exceto o algodão, são a segunda maior concentração no Brasil, 24,9\%, perfazendo um total de 207 empresas. O Sudeste é a região que concentra o maior número de estabelecimentos, assim como os de manufatura de algodão, correspondendo a $36,2 \%$ do total de empresas, seguido pelo Nordeste, com $32,4 \%$. Os mesmos estados que processam o algodão são os que manufaturam outras fibras naturais. As firmas que processam filamentos químicos estão localizadas no Sudeste $(65,1 \%)$ e no Sul $(20,1 \%)$ do Brasil. São Paulo e Santa Catarina são os estados que possuem a maior concentração de fábricas que processam filamentos químicos.

O país é produtor de fibras de algodão, sendo essa a principal fonte de matéria-prima de toda a cadeia têxtil-vestuário brasileira. Segundo as associações ligadas às empresas de fiação (Abrafas, Abrasseda, Febralã, Afipol e Conab), o consumo industrial de fibras naturais (algodão, seda, lã etc.) foi de aproximadamente 969 mil toneladas em 2009, e o consumo de filamentos químicos (artificiais e sintéticos) chegou a cerca de 660 mil toneladas. Sozinho, o algodão teve um consumo em torno de 948 mil toneladas, o que mostra sua importância na cadeia.

Com os ajustes pelos quais as empresas têm passado com a abertura comercial brasileira, o fim dos acordos têxteis e a competição no mercado global, muitas 
firmas modificaram suas estratégias, transferindo suas plantas para diferentes estados do país, alterando o produto a ser comercializado ou encerrando suas atividades. O reflexo desses ajustes dá-se no nível de emprego ofertado pelas organizações no país. A Tabela 13 mostra o volume de mão de obra empregada no período de 1995 a 2010.

Tabela 13 - Nº de Empregados no Elo de Fiação de Algodão, Fibras Naturais e Filamentos Químicos - 1995/2010

\begin{tabular}{|c|c|c|c|c|c|c|c|}
\hline $\mathrm{ANO}^{*}$ & Algodão & $\%$ & $\begin{array}{c}\text { Fibras Naturais, } \\
\text { não algodão }\end{array}$ & $\%$ & $\begin{array}{c}\text { Filamentos } \\
\text { Químicos }\end{array}$ & $\%$ & Total \\
\hline 1995 & 39.714 & 58,3 & 8.416 & 12,4 & 19.988 & 29,3 & 68.118 \\
\hline 2000 & 24.938 & 52,5 & 6.982 & 14,7 & 15.589 & 32,8 & 47.509 \\
\hline 2005 & 26.003 & 52,2 & 7.255 & 14,6 & 16.517 & 33,2 & 49.775 \\
\hline 2009 & 27.363 & 53,6 & 8.108 & 15,9 & 15.565 & 30,5 & 51.036 \\
\hline 2010 & 27.481 & 53,6 & 8.359 & 16,3 & 15.412 & 30,1 & 51.252 \\
\hline
\end{tabular}

Fonte: MTE/ Rais (2010). Elaboração própria.

Notas: Classe 13111, 13120,13138 - CNAE 20 - versão 2.0

(1) Classe 13111: Preparação e fiação de fibras de algodão

(2) Classe 13120: Preparação e fiação de fibras têxteis naturais, exceto algodão

(3) Classe 13138: Fiação de fibras artificiais e sintéticas

$\left(^{*}\right)$ O ano de 1990 não foi utilizado devido a não possuir os elos em separado

O elo da fiação, que gerava 68 mil empregos em 1995, teve uma queda de $24,7 \%$ nesse número, correspondendo, atualmente, a 51.252. Essa queda foi ocasionada, sobretudo, pelo segmento de algodão, que apresentou uma queda no número de empregos gerados de $31,8 \%$, em que contribuía para a ocupação de $58,3 \%$ dos trabalhadores em 1995, passando a contribuir com 53,6\% em 2010. A fiação de filamentos químicos também colabora para a diminuição do número de empregos no elo de fiação, com uma queda de 22,9\%. Apesar de a distribuição de emprego ser mais intensa nos segmentos de filamentos químicos e algodão, o de fibras naturais, excluído este último, foi o que se manteve estável, e com a queda dos outros segmentos, aumentou sua participação, passando de 12,4\% em 1995 para 16,3\% em 2010.

Ao serem analisadas as exportações brasileiras do elo fiação (Tabela 14), evidencia-se que a fibra de algodão é a que mais contribui nas vendas realizadas no país. 
Tabela 14 - Exportações Brasileiras de Fibras Naturais e de Filamentos Químicos - 1990/2009

\begin{tabular}{|c|c|c|c|c|c|c|c|c|c|}
\hline \multirow[b]{2}{*}{ ANO } & \multicolumn{2}{|l|}{ SEDA } & \multicolumn{2}{|c|}{ LÃ } & \multicolumn{2}{|c|}{ ALGODÃO } & \multicolumn{2}{|c|}{$\begin{array}{c}\text { FILAMENTOS } \\
\text { QUIMICOS* }^{*}\end{array}$} & \multirow{2}{*}{$\begin{array}{c}\text { TOTAL } \\
\text { US\$ } \\
\text { FOB }\end{array}$} \\
\hline & Milhões US\$ FOB & $\%$ & $\begin{array}{l}\text { US\$ } \\
\text { FOB }\end{array}$ & $\%$ & $\begin{array}{c}\text { Milhões US\$ } \\
\text { FOB }\end{array}$ & $\%$ & Milhões US\$ FOB & $\%$ & \\
\hline 1990 & 85,0 & 12,6 & 42,0 & 6,2 & 420,0 & 62,3 & 127,0 & 18,8 & 674,0 \\
\hline 1995 & 85,0 & 12,7 & 55,0 & 8,2 & 392,0 & 58,8 & 135,0 & 20,2 & 667,0 \\
\hline 2000 & 51,0 & 11,0 & 22,0 & 4,7 & 263,0 & 56,6 & 129,0 & 27,7 & 465,0 \\
\hline 2005 & 33,0 & 3,0 & 22,0 & 2,0 & 779,0 & 71,9 & 250,0 & 23,1 & $1.084,0$ \\
\hline 2010 & 35,0 & 2,6 & 35,0 & 2,6 & 997,0 & 75,1 & 261,0 & 19,6 & $1.328,0$ \\
\hline
\end{tabular}

Fonte: MDIC/Aliceweb (2011). Elaboração Própria.

Nota: $\left(^{\star}\right)$ Filamentos químicos incluem artificiais e sintéticos.

Capítulos 50 (seda), 51 (lã), 53 (algodão) 54 e 55 (filamentos químicos) NCM

O comportamento do algodão oscilou no período, mas foi o que apresentou o maior crescimento nas exportações, passando de $62,3 \%$ em 1990 para $75,1 \%$ do total de fios exportados em 2010. Dos fios naturais, a lã e a seda apresentaram quedas significativas nos valores exportados, com uma redução na participação de 6,2\% em 1990 para 2,6\% em 2010 e de $12,6 \%$ em 1990 para 2,6\% em 2010, respectivamente. No caminho contrário, os filamentos químicos, a despeito de algumas oscilações, apresentaram crescimento dos valores exportados, com uma variação nominal de 105\% no período, passando de 18,8\% em 1990 para 19,6\% em 2010.

Apesar do volume exportado, o país tem recorrido a crescentes importações, principalmente nos filamentos sintéticos. A Tabela 15 mostra a evolução das importações brasileiras entre 1990 e 2010.

Tabela 15 - Importações Brasileiras de Fibras Naturais e de Filamentos Químicos - 1990/2009

\begin{tabular}{|c|c|c|c|c|c|c|c|c|c|}
\hline \multirow[b]{2}{*}{ ANO } & \multicolumn{2}{|l|}{ SEDA } & \multicolumn{2}{|l|}{ LÃ } & \multicolumn{2}{|c|}{ ALGODÃO } & \multicolumn{2}{|c|}{$\begin{array}{c}\text { FILAMENTOS } \\
\text { QUIMICOS }\end{array}$} & \multirow{2}{*}{\begin{tabular}{|c|} 
TOTAL \\
Milhões US\$ \\
FOB \\
\end{tabular}} \\
\hline & $\begin{array}{c}\text { Milhões US\$ } \\
\text { FOB } \\
\end{array}$ & $\%$ & $\begin{array}{c}\text { Milhões US\$ } \\
\text { FOB }\end{array}$ & $\%$ & $\begin{array}{c}\text { Milhões US\$ } \\
\text { FOB }\end{array}$ & $\%$ & $\begin{array}{c}\text { Milhões US\$ } \\
\text { FOB }\end{array}$ & $\%$ & \\
\hline 1990 & 2,0 & 0,6 & 18,0 & 5,5 & 189,0 & 57,6 & 119,0 & 36,3 & 328,0 \\
\hline 1995 & 4,0 & 12,7 & 37,0 & 8,2 & 733,0 & 58,8 & 848,0 & 20,2 & $1.622,0$ \\
\hline 2000 & 4,0 & 11,0 & 21,0 & 4,7 & 366,0 & 56,6 & 729,0 & 27,7 & $1.120,0$ \\
\hline 2005 & 7,0 & 0,7 & 17,0 & 1,8 & 96,0 & 10,2 & 819,0 & 87,2 & 939,0 \\
\hline 2010 & 14,0 & 0,5 & 20,0 & 0,8 & 586,0 & 22,8 & $1.949,0$ & 75,9 & $2.569,0$ \\
\hline
\end{tabular}

Não obstante um crescimento nominal, evidencia-se uma diminuição das importações brasileiras de fibras naturais, passando de 77,6\% do total importado em 1990 para $24,1 \%$ em 2010 . O algodão teve um crescimento nominal nas importações de U\$\$ 397 milhões no período, mas sua participação no total das importações de fios e fibras, que era de 57,6\% em 1990, diminuiu para 22,8\% em 2010, devido ao aumento nas importações dos filamentos químicos. Estes, aliás, foram os que tiveram maior elevação no período tabulado. Em 1990, o valor importado foi de 
US $\$ 119$ milhões, passando para US $\$ 1,9$ bilhões em 2010, o que aumentou sua participação nas importações em 39,6 pontos percentuais. Isso se deve ao fato de o Brasil substituir em parte as fibras naturais por filamentos químicos e pela competitividade em relação ao preço do filamento importado em comparação ao nacional. A Tabela 16 mostra os países de quem o Brasil mais importou fibras naturais e filamentos químicos.

Tabala 16. Principais Paises de cuem o Brastincontou Fibras Naturais e de Flamentios Quimicos do Brast: 2010

\begin{tabular}{|c|c|c|c|c|c|c|c|c|c|c|c|}
\hline \multicolumn{3}{|c|}{ Seda } & \multicolumn{3}{|c|}{ Là } & \multicolumn{3}{|c|}{ Algod350 } & \multicolumn{3}{|c|}{ Filamentos Quinicos } \\
\hline Pás & $\begin{array}{c}\text { Mii } \\
\text { USS FOB }\end{array}$ & $\%$ & Pais & $\begin{array}{c}\text { III } \\
\text { USS FOB }\end{array}$ & $\%$ & Pàs & $\begin{array}{c}\text { MII } \\
\text { USSFOB }\end{array}$ & $\%$ & Pais & $\begin{array}{c}\text { Mii } \\
\text { USSFOB }\end{array}$ & $\%$ \\
\hline Ching & 97230 & & Unvogai & 8781,0 & & China & 206.1090 & & 2 China & 5330900 & 27,3 \\
\hline Infa & $1.67,0$ & & tâlia & $4.147,0$ & & hila & $203.195,0$ & & 7 India & 2095563,0 & 14.9 \\
\hline thála & 12110 & & Penv & 18020 & & Estados Unidos & 38.5830 & & Inonésia & $277.706,0$ & 14.2 \\
\hline Paraguai & 2420 & & China & 1708,0 & & Paragai & $27.819,0$ & & Fonnoza(Täinan) & $141.753,0$ & 7,3 \\
\hline Coreia do SUl & 2660 & & Angentina & 12290 & & Avgentina & 26.1450 & & Coreia do Sul & 1039330 & 5,3 \\
\hline Unguai & $\pi, 0$ & & Colombia & 938,0 & & Egto & $10.107,0$ & & Talända & $77.406,0$ & 40 \\
\hline Franca & 710 & & Estados Unibos & 5880 & & Espanha & $8.187,0$ & & 4 Estados Unidos & 69.6730 & 3.6 \\
\hline Reino Unido & 41,0 & & chile & 79,0 & & Turguia & 72090 & & Argentina & 50.1020 & 2,6 \\
\hline Estados Unidos & 160 & & Alemanha & 740 & & hodonésia & 4.1830 & & 7 Avemenha & 48.1200 & 25 \\
\hline Alemsanha & 140 & & India & 69,0 & & talia & 32580 & & Esparha & 17.629 .0 & 0.9 \\
\hline Qdtros & 6240 & & Outros & 522,0 & & Outoos & $50.763,0$ & & adtos & 340.4690 & 17,4 \\
\hline TOTAL & 139820 & 100, & TOTAL & $19.967,0$ & & TOTAL & 565.6390 & & TTOTAL & $1949.444,0$ & 100,0 \\
\hline
\end{tabular}

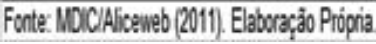

Nas importações realizadas pelo Brasil, a China possui maior participação em duas fibras naturais e nos filamentos químicos. Na seda, a China participa com $69,8 \%$ do total importado, no algodão, com $35,2 \%$ e nos filamentos químicos, com $27,3 \%$ em 2010. O Uruguai é o país do qual o Brasil mais importa lã, representando $44 \%$ do total importado nessa fibra em 2010, seguido da Itália, com 20,8\%. A liderança da China diante das importações de fibras e filamentos do Brasil mostra que as fiações estão buscando diminuir custos, principalmente no que se refere à aquisição de matéria-prima, nem sempre existente no país para suprir as demandas produtivas do elo em questão.

Assim, a evolução das importações brasileiras de fios, fibras e filamentos, cuja origem é a China, acaba por refletir nos custos dos demais elos, como o têxtil e o de confecções, ou seja, adquirindo a matéria-prima com custo menor, esta chega aos demais elos com um valor mais competitivo do que se fosse manufaturada no Brasil. 
O segundo elo da cadeia têxtil-vestuário é composto pela tecelagem de fibras naturais e dos filamentos químicos, fabricação de tecidos de malha, tapeçaria, cordoaria e especiais, como rendas e outros. Em 2010, esse elo da cadeia estava composto por 12.800 empresas espalhadas, em sua maioria, nas regiões Sudeste e Sul do país, tendo como principais estados produtores São Paulo, Minas Gerais, Santa Catarina e Rio Grande do Sul.

A concentração de estabelecimentos, assim como a fiação, está em São Paulo, tendo Minas Gerais como segundo maior estado em número de empresas têxteis em 2010, seguidos por Santa Catarina e Rio Grande do Sul.

Tabela 17: Estabelecimentos de tecelagem nos principais estados brasileiros - 2010

\begin{tabular}{l|r|r|}
\hline \multicolumn{1}{c|}{ UF } & Tecelagem & \multicolumn{1}{c|}{$\%$} \\
\hline São Paulo & 3.703 & 28,9 \\
\hline Minas Gerais & 2.152 & 16,8 \\
\hline Santa Catarina & 2.065 & 16,1 \\
\hline Rio Grande do Sul & 1.078 & 8,4 \\
\hline Outros & 3.802 & 29,8 \\
\hline Total & 12.800 & 100 \\
\hline
\end{tabular}

Fonte: MTE/RAIS (2011). Elaboração Própria

Nota: Div. CNAE 95 - Divisão de Atividade Econômica (59 categorias)

Divisão 17 - Fabricação de produtos têxteis

O número de estabelecimentos apresentou crescimento no período analisado, como pode ser visto na Tabela 18.

Tabela 18: Evolução do número de empresas no elo de tecelagem - 1995/2010

\begin{tabular}{rr|r}
\hline ANO & \multicolumn{2}{|c|}{ Tecelagem } \\
\hline 1995 & 9.145 \\
\hline 2000 & 9.416 \\
\hline 2005 & 10.735 \\
\hline 2010 & 12.800 \\
\hline
\end{tabular}

Fonte: MTE/ RAIS (2011). Elaboração própria.

O número de empresas aumentou no período, passando de 9.145 em 1995 para 12.800 em 2010. Essas fábricas são responsáveis pela ocupação de vários empregos no segmento têxtil. Do total de empregos na indústria de transformação em 2010, que foi cerca de 6 milhões, a cadeia têxtil-vestuário corresponde a cerca de $10 \%$ 
desse total (Abit, 2011). O elo da tecelagem é responsável por grande parte da mão de obra na cadeia têxtil-vestuário, como pode ser verificado na Tabela 19.

Tabela 19: Número de empregados na tecelagem - 1995/2010

\begin{tabular}{|r|r|}
\hline \multicolumn{1}{|c|}{ ANO } & \multicolumn{1}{|r|}{ Tecelagem } \\
\hline 1995 & 329.532 \\
\hline 2000 & 388.451 \\
\hline 2005 & 309.136 \\
\hline 2010 & 349.289 \\
\hline Fonte: MTE/ Rais (1995/2010). Elaboração própria. \\
Notas: Div. CNAE 95 - Divisão de Atividade Econômica (59 categorias) \\
\hline Divisão 17 - Fabricação de produtos têxteis \\
\hline
\end{tabular}

As empresas de médio e de grande porte são as que mais empregam nesse segmento, correspondendo a $63,3 \%$ do total de empregos, sendo as grandes empresas, com $32,2 \%$, as maiores empregadoras. O número de empregos do elo da tecelagem distribuídos por Estados está relacionado na Tabela 20.

Tabela 20: Mão de obra dos principais estados brasileiros no elo tecelagem: 2010

\begin{tabular}{l|r|r}
\hline \multicolumn{1}{|c|}{ UF } & Tecelagem & $\%$ \\
\hline São Paulo & 127.686 & 36,6 \\
\hline Santa Catarina & 70.384 & 20,1 \\
\hline Minas Gerais & 39.707 & 11,4 \\
\hline Ceará & 18.001 & 5,1 \\
\hline Paraná & 15.811 & 4,5 \\
\hline Rio Grande do Sul & 13.970 & 4,0 \\
\hline Bahia & 10.946 & 3,1 \\
\hline Paraíba & 9.207 & 2,6 \\
\hline Rio Grande do Norte & 8.665 & 2,5 \\
\hline Rio de Janeiro & 8.255 & 2,4 \\
\hline Outros & 26.657 & 7,7 \\
\hline Total & 349.289 & 100 \\
\hline
\end{tabular}

Fonte: MTE/RAIS (2011). Elaboração Própria

O faturamento da tecelagem divide-se em dois segmentos: o de tecidos planos e os de malha. Com relação à produção brasileira, a maior parte da produção abastece o mercado interno, enquanto uma parte menor é destinada para exportação 
(Depec, 2010). As exportações e importações brasileiras desse segmento são analisadas nas Tabelas 21, 22, 23 e 24.

Tabela 21: Exportações brasileiras de tecidos especiais, impregnados e de malha - 1990/2010

\begin{tabular}{|c|c|c|c|c|c|c|c|}
\hline & \multicolumn{2}{|c|}{ Tecidos Especiais } & \multicolumn{2}{|c|}{ Tecidos Impregnados } & \multicolumn{2}{|c|}{ Tecidos de Malha } & TOTAL \\
\hline ANO & $\begin{array}{c}\text { Milhões US\$ } \\
\text { FOB }\end{array}$ & $\%$ & $\begin{array}{c}\text { Milhões US\$ } \\
\text { FOB }\end{array}$ & $\%$ & $\begin{array}{c}\text { Milhões US\$ } \\
\text { FOB }\end{array}$ & $\%$ & $\begin{array}{c}\text { Milhões US\$ } \\
\text { FOB }\end{array}$ \\
\hline 1990 & 17,0 & 17,0 & 11,0 & 11,0 & 5,0 & 5,0 & $\overline{100,0}$ \\
\hline 1995 & 28,0 & 13,0 & 56,0 & 26,0 & 11,0 & 5,1 & 215,0 \\
\hline 2000 & 18,0 & 9,0 & 37,0 & 18,4 & 30,0 & 14,9 & 201,0 \\
\hline 2005 & 34,0 & 10,3 & 86,0 & 26,1 & 52,0 & 15,8 & 330,0 \\
\hline 2010 & 42,0 & 8,2 & 126,0 & 24,7 & 53,0 & 10,4 & 509,0 \\
\hline
\end{tabular}

Fonte: MDIC/Aliceweb (2011). Elaboração Própria.

Notas: Capitulos 58 (tecidos especiais), 59 (tecidos impregnados), 60 (tecidos de malha) NCM.

As exportações brasileiras de tecidos de 1990 a 2010 apresentaram crescimento, em todos os segmentos. As maiores exportações em 2010 concentraram-se nos tecidos impregnados, representando $57,1 \%$ do total exportado, sendo, também, o tecido onde as exportações mais cresceram no período. Nos tecidos em malha, a participação das exportações cresceu de 15,2\% em 1990 a 23,9\% em 2010, sendo o segundo segmento em exportações. Já os tecidos especiais diminuíram sua participação nas exportações, apesar do crescimento nominal, passando de 51,5\% em 1990 para 19\% em 2010. O comportamento das exportações dos tecidos de malha teve crescimentos constantes de 1990 a 2005, passando de $5 \%$ para $15,8 \%$ e reduzindo sua participação em 2010 para 10,4\%. A despeito dos valores exportados, o Brasil tem buscado, no comércio internacional, meios de suprir suas demandas e diminuir seus custos produtivos com matérias-primas mais baratas. A Tabela 22 evidencia a evolução das importações de tecidos no período de 1990 a 2010.

Tabela 22: Importações brasileiras de tecidos especiais, impregnados e de malha - 1990/2010

\begin{tabular}{r|r|r|r|r|r|r|r|}
\hline & \multicolumn{2}{|c|}{ Tecidos Especiais } & \multicolumn{2}{c|}{ Tecidos Impregnados } & \multicolumn{2}{c|}{ Tecidos de Malha } & \multicolumn{2}{c|}{ TOTAL } \\
\hline ANO & \multicolumn{1}{|c|}{$\begin{array}{c}\text { Milhões US\$ } \\
\text { FOB }\end{array}$} & \multicolumn{1}{c|}{$\begin{array}{c}\text { Milhões US } \\
\text { FOB }\end{array}$} & \multicolumn{1}{c|}{$\begin{array}{c}\text { Milhões US\$ } \\
\text { FOB }\end{array}$} & \multicolumn{1}{c}{$\begin{array}{c}\text { Milhos US\$ } \\
\text { FOB }\end{array}$} \\
\hline 1990 & 6,4 & 12,8 & 22,4 & 44,9 & 2,5 & 5,0 & 31,3 \\
\hline 1995 & 34,5 & 14,3 & 67,5 & 27,9 & 43,8 & 18,1 & 145,8 \\
\hline 2000 & 30,4 & 10,0 & 108,4 & 35,6 & 62,9 & 20,6 & 201,7 \\
\hline 2005 & 48,6 & 15,6 & 134,6 & 43,2 & 29,5 & 9,4 & 212,7 \\
\hline 2010 & 102,4 & 8,6 & 282,1 & 23,6 & 522,9 & 43,6 & 907,4 \\
\hline
\end{tabular}

Fonte: MDIC/Aliceweb (2011). Elaboração Própria. 
Percebe-se que a importação de tecidos cresceu significativamente no período, atingindo US\$ 907 milhões em 2010. O principal tecido importado é o de malha, representando $57,6 \%$ do total importado em 2010. Ele também é o que apresentou o maior crescimento nas importações do período analisado, representando $5 \%$ em 1990 e passando para 43,6\% em 2010. As importações de tecidos especiais apresentaram crescimento nominal no período, bem como a dos tecidos impregnados; porém, a participação de ambos diminui, representado, em 2010, 11,3\% e 31,1\%, respectivamente, do total importado. Os principais países dos quais o Brasil importou em 2010 são relacionados na Tabela 23.

Tabela 23: Principais países de quem o Brasil importou tecidos especiais, impregnados e de malha $-2010$

\begin{tabular}{|c|c|c|c|c|c|c|c|c|}
\hline \multicolumn{3}{|c|}{ Tecidos Especiais } & \multicolumn{3}{|c|}{ Tecidos Impregnados } & \multicolumn{3}{|c|}{ Tecidos de Malha } \\
\hline País & $\begin{array}{l}\text { Milhões } \\
\text { US\$ FOB }\end{array}$ & $\%$ & País & $\begin{array}{c}\text { Milhões } \\
\text { US\$ FOB }\end{array}$ & $\%$ & País & $\begin{array}{c}\text { Milhões } \\
\text { US\$ FOB }\end{array}$ & $\%$ \\
\hline China & 50,4 & 49,4 & China & 73,2 & 26,0 & China & 459,6 & 87,9 \\
\hline Argentina & 15,7 & 15,4 & Argentina & 41,2 & 14,6 & Coréia do Sul & 30,7 & 5,9 \\
\hline Tailândia & 3,9 & 3,8 & Estados Unidos & 33,0 & 11,7 & Uruguai & 4,7 & 0,9 \\
\hline Itália & 3,7 & 3,6 & Coréia do Sul & 29,7 & 10,5 & Formoza (Taiwan) & 4,4 & 0,9 \\
\hline Colômbia & 2,8 & 2,7 & Alemanha & 25,3 & 9,0 & Alemanha & 2,9 & 0,6 \\
\hline Formoza (Taiwan) & 2,8 & 2,7 & Itália & 14,0 & 5,1 & Espanha & 1,8 & 0,3 \\
\hline Coréia do Sul & 2,6 & 2,6 & Formoza (Taiwan) & 9,3 & 3,4 & Portugal & 1,8 & 0,3 \\
\hline Estados Unidos & 2,1 & 2,1 & França & 5,5 & 1,9 & Chile & 1,2 & 0,2 \\
\hline França & 1,2 & 1,2 & Espanha & 4,5 & 1,4 & Argentina & 1,2 & 0,2 \\
\hline Japão & 1,0 & 1,0 & México & 4,3 & 1,5 & Estados Unidos & 1,1 & 0,2 \\
\hline Outros & 15,8 & 15,5 & Outros & 42,0 & 14,9 & Outros & 13,6 & 2,6 \\
\hline TOTAL & 102,0 & 100,0 & TOTAL & 282,0 & 100,0 & TOTAL & 523,0 & 100,0 \\
\hline
\end{tabular}

Fonte: MDIC/Aliceweb (2011). Elaboração própria.

As importações do elo da tecelagem têm como principal fornecedor a China. Nos tecidos em malha, que representam o maior valor importado, a China foi o país do qual o Brasil mais importou, representando 87,6\% do total importado desse produto. Nos tecidos impregnados, que estão em segundo lugar no ranking de importações, a China também aparece como principal país de quem o Brasil importa, com uma participação de 26,0\%, seguida da Argentina (14,6\%), dos Estados Unidos $(11,7 \%)$ e da Coreia do Sul (10,5\%). Nos tecidos especiais, a China é a maior exportadora para o Brasil, com uma participação de 49,4\%, seguida da Argentina $(15,4 \%)$. Isso mostra a busca dos produtores brasileiros de matéria-prima com preços reduzidos para competirem no mercado interno, onde o faturamento brasileiro em tecidos corresponde a 97\%, segundo dados do Depec (2010). Assim, a Tabela 24 mostra a evolução das importações desse elo do mercado da China. 
Tabela 24: Importações brasileiras da China de tecidos especiais, impregnados e de malha $1990 / 2010$

Tabela 23- Importações Brasileiras da China de Tecidos Especiais, Impregnados e de Malha - 1990/2010

\begin{tabular}{r|r|r|r|r|r|r|r}
\hline & \multicolumn{2}{|c|}{ Tecidos especiais } & \multicolumn{2}{|c|}{ Tecidos Impregnados } & \multicolumn{2}{c|}{ Tecidos de Malha } & \multicolumn{1}{c}{ TOTAL } \\
\hline & & & & & & \\
ANO & Mil US\$ FOB & \multicolumn{1}{c|}{$\%$} & Mil US\$ FOB & \multicolumn{1}{c}{$\%$} & Mil US\$ FOB & \multicolumn{1}{c}{$\%$} & Mil US\$ FOB \\
\hline 1990 & 0,0 & 0,0 & 9,0 & 69,2 & 4,0 & 30,6 & 13,0 \\
\hline 1995 & 529,0 & 28,3 & 166,0 & 8,9 & $1.175,0$ & 62,8 & $1.870,0$ \\
\hline 2000 & $1.427,0$ & 30,3 & $3.012,0$ & 64,0 & 264,0 & 5,6 & $4.703,0$ \\
\hline 2005 & $9.778,0$ & 33,5 & $9.010,0$ & 30,9 & $10.363,0$ & 35,6 & $29.151,0$ \\
\hline 2010 & $50.414,0$ & 8,6 & $73.198,0$ & 12,6 & $459.607,0$ & 78,8 & $583.219,0$ \\
\hline
\end{tabular}

Fonte: MDIC/Aliceweb (2011). Elaboração própria.

Uma vez que a tecelagem compreende o elo anterior à confecção, ou seja, seu fornecedor, a busca por matérias-primas de baixo custo é fator importante para a competitividade, por ser intensivo em mão de obra e porque os seus custos impactam nesses dois elementos (matéria-prima e mão de obra).

Por fim, o elo de confecção, o último da produção na industrialização, é diversificado em termos de quantidade e tamanho dos estabelecimentos, mão de obra empregada e produtos fabricados. As empresas desse segmento, que são divididas em três tipos - vestuário em malha, vestuário em outros tecidos e outros artigos têxteis, onde se encontra a linha lar (cama, mesa e banho) -, concentram-se, principalmente, nas regiões Sudeste e Sul, tendo no estado de São Paulo o seu destaque. A Tabela 25 mostra a distribuição das empresas de confecção por estado do Brasil.

Tabela 25: Estabelecimentos de confecção nos principais estados brasileiros - 2010

\begin{tabular}{l|r|r}
\hline \multicolumn{1}{c|}{ UF } & \multicolumn{1}{|c|}{ Vestuário } & \multicolumn{1}{c}{$\%$} \\
\hline São Paulo & 14.669 & 27,5 \\
\hline Santa Catarina & 7.236 & 13,6 \\
\hline Minas Gerais & 6.591 & 12,4 \\
\hline Paraná & 4.990 & 9,4 \\
\hline Rio de Janeiro & 3.854 & 7,2 \\
\hline Goiás & 3.070 & 5,8 \\
\hline Ceará & 3.036 & 5,6 \\
\hline Rio Grande do Sul & 2.782 & 5,2 \\
\hline Outros & 7.070 & 13,3 \\
\hline Total & 53.298 & 100,0 \\
\hline
\end{tabular}

Fonte: MTE/RAIS (2011). Elaboração própria

Nota: Divisão CNAE 95 - Divisão de Atividade Econômica CNAE/95 (59 categorias)

Divisão 18 - Confecção de artigos do vestuário e acessórios 
O número de estabelecimentos de confecção no Brasil, que em 2010 totalizou 53.298, sendo São Paulo, Santa Catarina e Minas Gerais os estados com mais empresas instaladas, vem apresentando um crescimento significativo no período: de 32.111 empresas em 1995 passou para 53.298 em 2010 (Tabela 26).

Tabela 26: Evolução do número de empresas no elo de confecção 1995/2010

\begin{tabular}{rr|r|}
\hline ANO & \multicolumn{2}{|c|}{ Confecção } \\
\hline 1995 & 32.111 \\
\hline 2000 & 34.745 \\
\hline 2005 & & 42.066 \\
\hline 2010 & 53.298 \\
\hline
\end{tabular}

Fonte: MTE/RAIS (2011). Elaboração própria .

O elo de confecção apresenta um número elevado de empresas, sendo uma característica internacional do setor, em virtude de sua atratividade. Essa atração é explicada pelas reduzidas barreiras tecnológicas, visto que o equipamento básico é a máquina de costura e a técnica é amplamente divulgada no mundo todo.

Essa facilidade de abertura de novos empreendimentos favorece a geração de empregos, cujo número nesse segmento aumentou, no período tabulado, de 358 mil em 1995 para 683 mil em 2010, como demonstra a Tabela 27.

\begin{tabular}{rr|r|}
\hline ANO & \multicolumn{2}{|c|}{ Confecção } \\
\hline 1995 & 358.286 \\
\hline 2000 & 411.272 \\
\hline 2005 & 522.717 \\
\hline 2010 & 683.339 \\
\hline
\end{tabular}

Fonte: MTE/RAIS (2011). Elaboração própria .

Dos três elos produtivos do setor têxtil-vestuário (fiação, tecelagem e confecção), a confecção compreende a fase em que é necessária uma quantidade maior de mão de obra, sobretudo na atividade de costura, processo responsável por aproximadamente $80 \%$ do trabalho produtivo. Apesar dos estudos que buscam mudar esse aspecto, essa fase é dependente da habilidade e do ritmo da mão de obra, sendo essa composta, em especial, pelo gênero feminino. 
A distribuição de empregos concentra-se, principalmente, nas micro e pequenas empresas, diferentemente do setor de tecelagem, onde os empregos se concentram em médias e grandes empresas. O número de empregos gerados pelo elo de confecção, de acordo com o porte das empresas, é mostrado na Tabela 28.

Tabela 28: Distribuição da mão de obra por porte de empresa no elo de confecção: 2010

\begin{tabular}{|c|c|c|}
\hline \multirow[b]{2}{*}{ Tamanho } & \multicolumn{2}{|l|}{ Empregados } \\
\hline & $\mathrm{N}^{0}$ & $\%$ \\
\hline Microempresa & $218.815,0$ & 32,0 \\
\hline Pequena & $269.931,0$ & 39,5 \\
\hline Média & $128.102,0$ & 18,8 \\
\hline Grande & $66.491,0$ & 9,7 \\
\hline Total & $683.339,0$ & 100,0 \\
\hline
\end{tabular}

Fonte: MTE/ RAIS (2011). Elaboração própria.

A distribuição da mão de obra no setor concentra-se no Sudeste e no Sul, onde está a maioria das empresas, com destaque para São Paulo e Santa Catarina. Contudo, outros estados começam a apresentar um crescimento significativo, como pode ser visto na Tabela 29.

Tabela 28 - Mão de Obra dos Principais Estados Brasileiros no Elo de Confecção: 2010

\begin{tabular}{l|r|r|}
\hline \multicolumn{1}{|c|}{ UF } & Confecção & \multicolumn{1}{|c|}{$\%$} \\
\hline São Paulo & 176.864 & 25,9 \\
\hline Santa Catarina & 102.856 & 15,1 \\
\hline Minas Gerais & 78.223 & 11,5 \\
\hline Paraná & 74.964 & 11,0 \\
\hline Rio de Janeiro & 55.008 & 8,0 \\
\hline Ceará & 52.916 & 7,7 \\
\hline Rio Grande do Norte & 22.897 & 3,3 \\
\hline Goiás & 22.743 & 3,3 \\
\hline Rio Grande do Sul & 22.592 & 3,3 \\
\hline Pernambuco & 20.320 & 3 \\
\hline Outros & 53.956 & 7,9 \\
\hline Total & 683.339 & 100,0 \\
\hline
\end{tabular}

Fonte: MTE/ RAIS (2011). Elaboração própria. 
Percebe-se que o estado do Rio Grande do Sul é o $9^{\circ}$ em geração de empregos nesse segmento. Já o Ceará, o Rio Grande do Norte e Pernambuco têm aumentado o número de empregados em relação a estados do Sul. Parte desse crescimento deve-se à transferência de plantas para os estados do Nordeste com vistas a diminuir custos, gerando mais emprego nesses estados e diminuindo a sua oferta em outros.

O faturamento do elo de confecção foi de aproximadamente US\$ 43 bilhões em 2008. O vestuário é responsável por cerca de $82 \%$, seguido da linha lar, com 7\%; meias e acessórios correspondem a 3\% e outros confeccionados perfazem $7 \%$. Por conta do mercado interno ficam cerca de $97 \%$ do total produzido no país, sendo destinados à exportação apenas $3 \%$. Para suprir o mercado interno, estão sendo importados alguns produtos com uma significativa participação. $\mathrm{O}$ comércio internacional desse setor é mostrado nas Tabelas 30, 31, 32 e 33, iniciando-se com a análise das exportações brasileiras do segmento.

Tabela 30: Exportações brasileiras de vestuário em malha, vestuário não malha e outros confeccionados - 1990/2010

\begin{tabular}{|c|c|c|c|c|c|c|c|}
\hline & \multicolumn{2}{|c|}{ Vestuário em Malha ${ }^{1}$} & \multicolumn{2}{|c|}{ Vestuário Não Malha ${ }^{2}$} & \multicolumn{2}{|c|}{ Outros Confeccionados ${ }^{3}$} & Total \\
\hline ANO & Milhões US\$ FOB & $\%$ & Milhões US\$ FOB & $\%$ & Milhões US\$ FOB & $\%$ & Milhões US\$ FOB \\
\hline 1990 & 121,5 & 28,5 & 113,2 & 26,5 & 191,8 & 45,0 & 426,5 \\
\hline 1995 & 154,3 & 29,3 & 127,2 & 24,1 & 245,4 & 46,6 & 526,9 \\
\hline 2000 & 184,0 & 34,4 & 91,0 & 17,0 & 260,1 & 48,6 & 535,1 \\
\hline 2005 & 201,8 & 26,6 & 150,6 & 19,9 & 405,8 & 53,5 & 758,2 \\
\hline 2010 & 102,8 & 26,5 & 73,8 & 19,0 & 211,6 & 54,5 & 388,2 \\
\hline
\end{tabular}

Fonte: MDIC/Aliceweb (2011). Elaboração própria.

Notas: Capítulo 61, 62 e 63 - NCM

(1) Capítulo 61: Vestuário e seus acessórios, de malha

(2) Capítulo 62: Vestuário e seus acessórios, exceto malha

(3) Capítulo 63: Outros confeccionados (linha lar)

As exportações de confecções brasileiras, que totalizaram US\$ 388 milhões em 2010, apresentam oscilações durante o período analisado, evidenciando crescimento do valor exportado até 2005, quando se inverte essa tendência e tem início um período de queda acentuada, que culmina com uma diminuição de $48,81 \%$ do volume exportado, se comparado o ano de 2010 com o de 2005 . Analisados por linha de produtos confeccionados, percebe-se que ambos apresentaram diminuição nas exportações, nos últimos cinco anos, sendo esta de maneira uniforme. Os outros confeccionados (54,5\%) são responsáveis pelo maior volume exportado em 2010.

As importações de vestuário-confecção seguiram caminho diferente do das exportações, com um aumento significativo, principalmente, nos últimos cinco anos. De US\$ 54 milhões em 1990 passaram para US\$259,7 milhões em 2005, culminando com aproximadamente US\$1.237,3 um vírgula dois bilhões em 2010. A evolução dessas importações está representada na Tabela 31. 
Tabela 31: Importações brasileiras de vestuário em malha, vestuário não malha e outros confeccionados - 1990/2010

\begin{tabular}{r|r|r|r|r|r|r|r|}
\hline & \multicolumn{2}{|c|}{ Vestuário em Malha } & \multicolumn{2}{c|}{ Vestuário Não Malha } & \multicolumn{2}{c|}{ Outros Confeccionados } & \multicolumn{1}{c}{ Total } \\
\hline \multicolumn{1}{c|}{ ANO } & Milhões US\$ FOB & \multicolumn{1}{c|}{$\%$} & Milhões US\$ FOB & $\%$ & Milhões US\$ FOB & $\%$ & Milhões US\$ FOB \\
\hline & & & & & & & \\
1990 & 12,5 & 23,1 & 34,4 & 63,7 & 7,1 & 13,2 & 54,0 \\
\hline 1995 & 93,7 & 26,5 & 216,1 & 61,3 & 43,1 & 12,2 & 352,9 \\
\hline 2000 & 48,3 & 28,5 & 92,5 & 54,6 & 28,6 & 16,9 & 169,4 \\
\hline 2005 & 72,6 & 28,0 & 154,5 & 59,5 & 32,6 & 12,5 & 259,7 \\
\hline 2010 & 456,6 & 36,9 & 616,4 & 49,8 & 164,3 & 13,3 & $1.237,3$ \\
\hline
\end{tabular}

Fonte: MDIC/Aliceweb (2011). Elaboração própria.

O expressivo aumento nas importações ocorreu nos três tipos de vestuário: malha, não malha e outros confeccionados. O vestuário não malha é o mais importado pelo Brasil, totalizando US\$ 616,4 milhões, seguido pelo vestuário em malha. Na Tabela 32, são demonstrados os países de quem o Brasil mais importou.

Tabela 32: Principais países de quem o Brasil importou vestuário em malha, vestuário não malha e outros confeccionados: 2010

\begin{tabular}{|c|c|c|c|c|c|c|c|c|}
\hline \multicolumn{3}{|c|}{ Vestuário em Malha } & \multicolumn{3}{|c|}{ Vestuário Não Malha } & \multicolumn{3}{|c|}{ Outros Confeccionados } \\
\hline País & $\begin{array}{c}\text { Milhões } \\
\text { US\$ }\end{array}$ & $\%$ & País & $\begin{array}{c}\text { Milhões } \\
\text { US\$ }\end{array}$ & $\%$ & País & $\begin{array}{c}\text { Milhões } \\
\text { US\$ }\end{array}$ & $\%$ \\
\hline China & 218,8 & 47,9 & China & 424,7 & 68,9 & China & 89,8 & 54,7 \\
\hline Bangladesh & 48,9 & 10,7 & Bangladesh & 21,6 & 3.5 & Paraguai & 12,2 & 7,4 \\
\hline Peru & 36,3 & 7.9 & Itália & 11,6 & 1,9 & Estados Unidos & 12,0 & 7,3 \\
\hline Argentina & 16,4 & 3,6 & Hong Kong & 10,4 & 1,7 & Uruguai & 7,2 & 4,4 \\
\hline Indonésia & 14,0 & 3,1 & Espanha & 9,7 & 1,6 & Hong Kong & 3,7 & 2,2 \\
\hline Hong Kong & 11,6 & 2,5 & Paraguai & 9,5 & 1,5 & Chile & 3,6 & 2,2 \\
\hline Tailândia & 8,6 & 1.9 & Indonésia & 9,0 & 1,5 & Argentina & 3,2 & 1,9 \\
\hline Itália & 6,6 & 1,5 & Portugal & 8,0 & 1,3 & Itália & 1,7 & 1,0 \\
\hline Estados Unidos & 5,5 & 1,2 & Uruguai & 7,2 & 1.2 & México & 1,3 & 0,8 \\
\hline Portugal & 4,9 & 1,1 & Argentina & 5,9 & 1,0 & Portugal & 0,9 & 0,6 \\
\hline Outros & 85,0 & 18,6 & Outros & 98,8 & 15,9 & Outros & 28,7 & 17,5 \\
\hline TOTAL & 456,6 & 100,0 & TOTAL & 616,4 & 1000 & TOTAL & 164,3 & 100,0 \\
\hline
\end{tabular}

Fonte: MDIC/Aliceweb (2011). Elaboração própria.

A evolução das importações de confecções com proveniência da China (Tabela 33) mostra que esse país vem conquistando espaço nas transações comerciais do Brasil. 
Tabela 33: Importações brasileiras da China em vestuário de malha, vestuário não malha e outros confeccionados - 1990/2010

\begin{tabular}{|c|c|c|c|c|c|c|c|c|}
\hline \multicolumn{3}{|c|}{ Vestuário em Malha } & \multicolumn{3}{|c|}{ Vestuário Não Malha } & \multicolumn{3}{|c|}{ Outros Confeccionados } \\
\hline País & $\begin{array}{c}\text { Milhões } \\
\text { US\$ }\end{array}$ & $\%$ & Pais & $\begin{array}{c}\text { Milhões } \\
\text { US\$ }\end{array}$ & $\%$ & País & $\begin{array}{c}\text { Milhões } \\
\text { US\$ }\end{array}$ & $\%$ \\
\hline China & 218,8 & 47,9 & China & 424,7 & 68,9 & China & 89,8 & 54,7 \\
\hline Bangladesh & 48,9 & 10,7 & Bangladesh & 21,6 & 3,5 & Paraguai & 12,2 & 7,4 \\
\hline Peru & 36,3 & 7,9 & Itália & 11,6 & 1,9 & Estados Unidos & 12,0 & 7,3 \\
\hline Argentina & 16,4 & 3,6 & Hong Kong & 10,4 & 1,7 & Uruguai & 7,2 & 4,4 \\
\hline Indonésia & 14,0 & 3,1 & Espanha & 9,7 & 1,6 & Hong Kong & 3,7 & 2,2 \\
\hline Hong Kong & 11,6 & 2,5 & Paraguai & 9,5 & 1,5 & Chile & 3,6 & 2,2 \\
\hline Tailândia & 8,6 & 1,9 & Indonésia & 9,0 & 1,5 & Argentina & 3,2 & 1,9 \\
\hline Itália & 6,6 & 1,5 & Portugal & 8,0 & 1,3 & Itália & 1,7 & 1,0 \\
\hline Estados Unidos & 5,5 & 1,2 & Uruguai & 7,2 & 1,2 & México & 1,3 & 0,8 \\
\hline Portugal & 4,9 & 1,1 & Argentina & 5,9 & 1,0 & Portugal & 0,9 & 0,6 \\
\hline Outros & 85,0 & 18,6 & Outros & 98,8 & 15,9 & Outros & 28,7 & 17,5 \\
\hline TOTAL & 456,6 & 100,0 & TOTAL & 616,4 & 100,0 & TOTAL & 164,3 & 100,0 \\
\hline
\end{tabular}

As importações provenientes da China, que praticamente não existiam em 1990, encerraram, em 2010, em aproximadamente US\$ 733 milhões. As maiores importações em 2010 foram de vestuário não malha, com US\$ 424 milhões, 57,9\% do total, seguido do vestuário em malha, com US\$218,8 milhões, que representa $29,8 \%$ do total importado. Os outros confeccionados, que incluem a linha lar e sacarias, são o terceiro em importações, com US\$ 89,8 milhões, representando 12,2\%.

Em síntese, verifica-se que a evolução da cadeia têxtil-vestuário no início da década de 1990, diante da abertura comercial, levou a que a maioria das empresas empreendesse um ajuste defensivo, caracterizado pela redução de pessoal em alguns elos, buscando maior eficiência no processo produtivo (introdução de inovações organizacionais e melhorias dos sistemas de qualidade), terceirização de atividades e especialização da produção, bem como o crescimento das importações de insumos.

Outro fator que desencadeou estratégias diferenciadas entre os elos foi a busca pela redução de custos, relativos tanto aos insumos quanto à mão de obra. Uma dessas táticas foi o deslocamento regional, sobretudo para o Nordeste brasileiro e demais regiões de incentivo, formando cooperativas de trabalho e diminuindo custos de mão de obra. Além disso, de acordo com Bastos (1993), as empresas adequaram-se ao cenário global, diversificando sua linha de produtos ou reduzindo o mix para produtos ou de baixo custo ou diferenciados. Os esforços empreendidos pelas firmas compreendem a participação de encontros de moda, a especialização em produtos de maior valor agregado, a formação de polos para compras conjuntas ou trocas de conhecimentos entre as empresas, bem como estratégias de distribuição, marca e contínua melhoria na qualidade dos produtos.

Outra estratégia encontrada foi a importação de produtos, visando a agregar algo que as empresas não detinham: tecnologia (maquinário especializado para a produção), aumentando, assim, o portfólio de produtos. Contudo, apesar desses 
esforços, "a presença agressiva da China e de outros países asiáticos no comércio internacional nos últimos anos com seus produtos baratos têm despertado a apreensão de empresas, de trabalhadores e de governos de diferentes países" (COSTA, 2007).

A competitividade gerada por esses concorrentes não está relacionada somente ao custo de seus produtos, mas também à atração que a China exerce sobre os produtores internacionais, que deslocam suas atividades de produção, subcontratando de empresas chinesas em vez de investir no país (COSTA, 2007). Outro fator tem sido a dificuldade quanto à aquisição do algodão, principal matéria-prima brasileira, devido à alta dos preços da fibra em 2009 e 2010. Isso levou a que empresas da cadeia têxtil substituíssem parte de algodão por filamentos químicos, e outras firmas importassem o tecido ou a confecção pronta principalmente da China.

Com isso, as empresas que têm utilizado a estratégia de diferenciação, buscando agregar valor ao produto, vêm obtendo resultados satisfatórios, apesar dos entraves a que o setor está suscetível.

\section{Considerações finais}

Considerando-se o objetivo deste trabalho - identificar os impactos na cadeia têxtil-vestuário do Brasil após a abertura do comércio brasileiro ao mercado mundial, principalmente em relação à indústria chinesa -, podem ser feitas algumas considerações acerca das informações obtidas.

Inicialmente, retratou-se o comércio internacional da cadeia têxtil-vestuário, destacando a participação da China nesse cenário. Evidenciou-se que, do total exportado no elo de fiação pelo mundo (fibras e filamentos), com cerca de US\$ 112,6 bilhões em 2009, a China vem se apresentando como um dos principais países exportadores na seda (46,5\%), no algodão (23,9\%) e nos filamentos químicos $(22,7 \%)$. Já países como Estados Unidos, Itália e Brasil tiveram sua participação diminuída em fibras e fios de algodão. Ficou evidenciado que a China, no elo da fiação, vem tomando espaço no mercado antes ocupado por outros países e tornando-se uma das principais fornecedoras mundiais.

No elo da tecelagem e da malharia, a participação da China tem sido mais intensa desde 2005. Do total exportado mundialmente em 2009 (cerca de US\$ 50,7 bilhões) em tecidos especiais, impregnados e de malha, a China exportou a outros países 27,4\%. Alemanha, Itália e Estados Unidos, nesse elo, perderam posição de mercado para a China.

Dentre os países que têm comercializado com a China, destacam-se alguns da própria Ásia, como Hong Kong (tecidos especiais e de malha), Índia (tecidos impregnados) e Vietnã (tecidos impregnados e de malha), além dos Estados Unidos, 
que adquire os três tipos de tecido, e do Brasil, que foi o $3^{\circ}$ importador de seus tecidos de malha (cerca de US\$293 milhões). A hegemonia da China, nesse elo, impacta nas estratégias dos demais países, visto que o produto fabricado pelos chineses envolve um custo de produção barato e atende aos níveis de qualidade exigidos pelos padrões internacionais. Apesar de os tecidos terem um custo reduzido para serem comercializados para o próximo elo, composto pelas confecções, isso não é fator impeditivo para que se deixe de importar da China o produto pronto.

No elo da confecção, o mercado mundial exportou US $\$ 338$ bilhões em 2009; destes, $34,7 \%$ têm procedência do mercado chinês, o equivalente a US $\$ 117,3$ bilhões em vestuário de malha, vestuário em outras fibras e outros confeccionados. Trata-se de um aumento significativo das exportações da China para o mercado mundial, se comparado com o ano de 1990, quando exportou US\$ 7 bilhões.

Diante desse "dragão chinês", muitos países ajustaram seus negócios no intuito de diminuir os impactos causados pela crescente importação de produtos pela cadeia têxtil-vestuário. As empresas não só se especializaram em marketing de nichos, visando a enfrentar os baixos preços dos produtos de origem chinesa, como também buscaram inovações no desenvolvimento de produtos e diferenciação. Além disso, aderiram ao uso de redes de cadeia de suprimentos e sourcing global, com vistas à diminuição de custos e ao aumento da produtividade, bem como à modalidade de "pacote completo - full package", que assegura às empresas estrangeiras o fornecimento de roupas prontas pelas firmas chinesas. As ligações entre inovação tecnológica, diferentes tipos de estratégias de internacionalização e o relacionamento com os varejistas formam um mapa global de produção e comércio mais complexo do que a simples explicação baseada nas diferenças de custos de mão de obra, fator característico da China.

De fato, a China tem emergido nas últimas décadas como um dos principais mercados de exportação para muitos países, inclusive para o Brasil. Assim, em um segundo momento, foram analisadas a configuração das empresas da cadeia têxtil-vestuário brasileira e as próprias empresas no comércio mundial.

As empresas da cadeia têxtil-vestuário estão localizadas, principalmente, nas regiões Sudeste e Sul do país, concentrando-se nos estados de São Paulo, Minas Gerais, Santa Catarina e Rio Grande do Sul, os maiores geradores de mão de obra nos três elos da cadeia. Percebe-se, todavia, um fenômeno de migração dos empregos para a região Nordeste (principalmente Ceará) motivada pelos incentivos tributários e pelo custo de mão de obra mais baixo.

Aprofundando a análise da cadeia têxtil-vestuário brasileira, observou-se que o volume de empregos, no elo de fiação, diminuiu significativamente no período, passando de 68 mil empregos em 1995 para 51 mil em 2010. Essa redução pode ser justificada pela opção das empresas em diminuir a produção de fios, passando a importar mais e concentrando suas atividades, principalmente, no segmento de 
confecção, somada a um movimento de modernização do parque fabril. Ao contrário, nos elos da tecelagem e de confecção, houve um aumento na quantidade de mão de obra. Na tecelagem, o número de funcionários passou de 329 mil em 1995 para 349 mil em 2010. Na confecção, o aumento foi considerável, de 358 mil em 1995 para 683 mil em 2010.

Com relação à participação do Brasil no comércio internacional da cadeia têxtil-vestuário, verificou-se que as exportações e as importações não mostraram a mesma evolução no período de 1990 a 2010. Em 2010, o Brasil exportou US $\$ 1,3$ bilhão na fiação, US\$ 221 milhões na tecelagem e US\$ 388 milhões na confecção, correspondendo, quando comparado com dados de 1990, a um aumento de $97 \%$ na fiação, de $569 \%$ na tecelagem e a uma diminuição de $9 \%$ na confecção.

Já as importações brasileiras tiveram um aumento maior do que as exportações no mesmo período. No elo de fiação, no período de 1990 a 2010, passaram de US\$ 328 milhões para US\$ 2,6 bilhões, com variação de $692 \%$. No elo da tecelagem, o crescimento no mesmo período foi de US\$ 36 milhões em 1990 para US\$ 907 milhões, representando um aumento de $2.400 \%$. Por fim, no elo da confecção, as importações em 1990 foram de US $\$ 54$ milhões e em 2010, de US\$ 1,2 bilhões, correspondendo a um aumento de $2.122 \%$. Quando apurado o resultado comercial do Brasil, em 2010, o segmento têxtil-vestuário apresentou um déficit de US\$2,8 bilhões, o que mostra o impacto das importações para o país nessa cadeia.

As importações têm se concentrado especialmente no mercado chinês, principal fornecedor nas fibras naturais e filamentos químicos $(29,5 \%)$, nos tecidos (64\%) e na confecção (59\%), não somente pelos preços competitivos, mas também pela atratividade exercida sobre os produtores internacionais, que deslocam suas atividades de produção, subcontratando da China em vez de investir no país. Também, a dificuldade na aquisição do algodão, matéria-prima brasileira mais importante, devido à alta dos preços da fibra em 2009 e 2010, levou a que empresas da cadeia têxtil substituíssem parte dessa fibra por filamentos químicos, aumentando as importações de fibras, tecidos e confecções da China. Com isso, as firmas que têm utilizado a estratégia de diferenciação, buscando agregar valor ao produto, vêm obtendo resultados satisfatórios, apesar dos entraves a que está suscetível o setor.

São necessárias políticas públicas no que se refere à redução dos impostos, além de uma política monetária com base na qual o governo possa controlar o câmbio, criar barreiras comerciais, melhorar as exportações nacionais, bem como possibilitar a desoneração dos encargos da folha de pagamento da mão de obra de todos os elos da cadeia. Se mantido o atual cenário, em termos político-monetários e de tributação, as estratégias relativas à importação para redução de custos e aumento do portfólio poderão ser ampliadas nos próximos períodos, abrindo ainda mais espaço para impactos na cadeia têxtil-vestuário. 


\title{
China in textile-clothing chain: impacts after the opening of Brazilian trade to world market and the end of Multi Fiber Agreement (MFA) Textile-Clothing Agreement (TCA)
}

\begin{abstract}
Intensive labor sectors in Brazil as footwear, furniture and clothing undergo strong competitive pressures, due to the presence, in their markets, of Asian competitors which has a more productive environment and more favorable to competitiveness. This study aimed to investigate China's share in global textiles and clothing market and trade relations with Brazil from 1990 to 2009, driven by the end of the MFA and TCA trade agreements. The informational basis of the study consists of data from national and international institutions. It was observed that China's presence in the international clothing and textiles market increased, placing the country as the world's leading exporter. Regarding Brazilian market the study showed that in the textile and apparel industries the main impacts were reduction of labor employed and increase in imports.
\end{abstract}

Keywords: Textiles and clothing chain. Chinese market. Competitive strategy. Trade agreements.

\section{China en la cadena textil - vestuario: impactos tras la apertura del comercio brasilero al mercado mundial y del fin de los acuerdos Multifibras (AMF) y textil Vestuario (ATV)}

\section{Resumen}

Sectores intensos en mano de obra en Brasil como los de calzados, de muebles y de confecciones pasan por fuertes presiones competitivas, debido a la presencia en sus mercados de actuación de competidores asiáticos, que poseen un ambiente productivo propicio a la competitividad. Este estudio tubo como objetivo investigar la participación de China en el mercado textil- vestuario mundial en las relaciones comerciales con Brasil desde el año 1990 hasta 2009, movida por la conclusión de los acuerdos comerciales AMF y ATV. La fuente de información del presente estudio esta compuesta por datos provenientes de instituciones nacionales e internacionales. Lo que se observa es que la presencia de China en el mercado internacional textil -vestuario aumentó, posicionando a ese país como el principal exportador mundial. Con relación al mercado Brasilero el estudio demostró que en la industria textil y de vestuario los principales impactos fueron la reducción de mano de obra empleada y el aumento de las importaciones.

Palabras clave: Cadena textil-vestuario. Mercado Chino. Estrategia competitiva. Acuerdos comerciales 


\section{Nota}

1 Investimentos de valor significativo são feitos na infraestrutura: rodovias, ferrovias, aeroportos, portos, além de internet e linhas telefônicas fixas e móveis. Planos quinquenais desenvolvem ações como: moeda desvalorizada e câmbio fixo; juros baixos, em torno de 2 a $3 \%$ ao ano; carga tributária em torno de $13 \%$ do valor do PIB e criação de Câmara de Comércio para Importação e Exportação de Têxteis da China (CCCT).

\section{Referências}

AMORIM, Alberto Henrique. Competitividade internacional do complexo têxtil brasileiro no período 1998 a 2006. Redige - Revista de Design, Inovação e Gestão Estratégica, Rio de Janeiro, v. 2 , n. 1, p. 83-104, 2011.

ASSOCIAÇÃO BRASILEIRA DA INDÚSTRIA TÊXTIL (Abit). Dados estatísticos do setor. São Paulo. Disponível em: <http://www.abit.org.br>. Acesso em: 14 out. 2010.

ASSOCIAÇÃO BRASILEIRA DO VESTUÁRIO (Abravest). Dados estatísticos do setor. São Paulo. Disponível em: <http://www.abravest.org.br/index.php>. Acesso em: 08 set. 2009.

BASTOS, Carlos Pinkusfelt Monteiro. Estudo da competitividade da indústria brasileira: competitividade da indústria de vestuário - nota técnica setorial do complexo têxtil. Campinas: IE/ Unicamp - IEI/UFRJ-FDC-Funcex, 1993.

CASTILHOS, Clarice C.; PASSOS, Maria Cristina (Coord.). Competitividade e inovação na indústria gaúcha. São Leopoldo: Ed. Unisinos; Porto Alegre: FEE, 1998

CENTRO DE TECNOLOGIA DA INDÚSTRIA QUÍMICA E TÊXTIL (Cetiqt). Avaliação estrutural da cadeia produtiva têxtil e de vestuário. Rio de Janeiro: Instituto de Prospecção Tecnológica e Mercadológica, 2003.

CHINA NATIONAL TEXTILE INDUSTRY COUNCIL (CNTIC). Instituto de prospecção tecnológica (IPTM). China: a competitividade da indústria têxtil e o setor de confeccionados. Rio de Janeiro: Senai/Cetiqt, 2004.

COSTA, Achyles Barcelos da. Instituições e competitividade no arranjo calçadista do Vale do Sinos. In: ENCONTRO NACIONAL DE ECONOMIA - ASSOCIAÇÃO NACIONAL DOS CENTROS DE PÓS-GRADUAÇÃO EM ECONOMIA - Anpec, 35, 2007, Rio de Janeiro. Anais... Rio de Janeiro, 2007. Disponível em: <http://econpapers.repec.org/scripts/redir.pf?u=http\%3A\%2F\%2Fwww. anpec.org.br\%2Fencontro2007\%2Fartigos\%2FA07A083.pdf;h=repec:anp:en2007:083>. Acesso em: 09 mar. 2011.

COSTA, Ana Cristina Rodrigues da; ROCHA, Érico Rial Pinto da. BNDES setorial. Rio de Janeiro, n. 29, p. 159-202, mar. 2009.

COUTINHO, Luciano G. et al. Estudo da competitividade da indústria brasileira: competitividade do complexo têxtil - nota técnica do complexo. Campinas: IE/Unicamp-IEI/UFRJ-FDC-Funcex, 1993.

DANTAS, Alexis; KERTSNETZKY, Jacques; PROCHNIK, Victor. Empresa, indústria e mercados. In: KUPFER, David; HASENCLEVER, Lia (Orgs.) Economia industrial. Rio de Janeiro: Campus, 2002. 
DEPARTAMENTO DE PESQUISAS E ESTUDOS ECONÔMICOS (Depec). Têxtil e confecções. Bradesco, out. 2010.

DICKEN, Peter. Mudança global: mapeando as novas fronteiras da economia mundial. 5. ed. Porto Alegre: Bookman, 2009.

FAJNZYLBER, Fernando. Competitividad internacional: evolución y lecciones. Revista de La Cepal, Chile, n. 36, p. 1-24, dez. 1988.

GRAHAM, Ian; KILDUFF, Peter. Textiles and clothing in China. London: Pearson Professional, 1994. (Financial Times Management Reports).

GEREFFI, Gary. International trade and industrial upgrading in the apparel commodity chain. Journal of International Economics, Durham, USA, v. 48, p. 37-70, 1999.

Local cluster in global chains: The causes and consequences of export dynamism in Torreon's Blue Jeans Industry. World Development, New Haven, USA, v. 29, n. 11, p. 1885-1903, 2001.

HAGUENAUER, Lia et al. Evolução das cadeias produtivas brasileiras na década de 90. Brasília: Ipea, 2001. (Texto para Discussão n. 786).

INSTITUTO EUVALDO LODI (IEL); CONFEDERAÇÃO NACIONAL DA AGRICULTURA (CNA); SERVIÇO DE APOIO ÀS MICRO E PEQUENAS EMPRESAS (Sebrae). Análise da eficiência econômica e da competitividade da cadeia têxtil brasileira. Brasília: IEL, 2000.

INSTITUTO DE ESTUDOS E MARKETING INDUSTRIAL (Iemi). Brasil Têxtil 2008 - Relatório Setorial da Indústria Têxtil Brasileira, São Paulo, v. 8, n. 8, p. 1-152, ago. 2008.

INSTITUTO NACIONAL DE PROPRIEDADE INDUSTRIAL (Inpi). Disponível em: <http:// www.inpi.gov.br/principal? navegador=IE\&largura=1440\&altura=900> Acesso em: 09 set. 2010 .

KUPFER, David. Barreiras estruturais à entrada. In: KUPFER, David; HASENCLEVER, Lia (Org.). Economia industrial. Rio de Janeiro: Campus, 2002.

LOOTY, Mariana; SZAPIRO, Marina. Economias de escala e escopo. In: KUPFER, David; HASENCLEVER, Lia (Org.). Economia industrial. Rio de Janeiro: Campus, 2002.

MARSHALL, Alfred. Princípios de economia: tratado introdutório. Trad. de Rômulo de Almeida e Ottolmy Strauch. São Paulo: Abril Cultural, 1982.

MINISTÉRIO DE DESENVOLVIMENTO, INDÚSTRIA E COMÉRCIO EXTERIOR (MDIC/Alice). Sistema de análise das informações de comércio exterior. Disponível em: <http://www.mdic. gov.br/sitio/alice>. Acesso em: 12 mar. 2011.

MINISTÉRIO DO TRABALHO E EMPREGO. Relação Anual de Informações Sociais - Rais. Disponível em: <http://sgt.caged.gov.br/XOLAPW.dll/fsmMain?C=false\&D=false >. Acesso em: 18 maio 2011.

MELLO, Maria Tereza Leopardi. Defesa da concorrência. In: KUPFER, David; HASENCLEVER, Lia (Orgs.). Economia industrial. Rio de Janeiro: Campus, 2002.

MINTZBERG, Henry. O processo da estratégia. In: MINTZBERG, Henry; QUINN, James Brain (Org). Trad. de James Sunderland Cook. 3. ed. Porto Alegre: Bookman, 2001.

NELSON, Richard R. WINTER, Sidney G. Uma teoria evolucionária da mudança econômica. Trad. de Cláudia Heller. Campinas, SP: Ed. Unicamp, 2005. 
PAVITT, Keith. Sectoral patterns of technical change: towards a taxonomy and theory. Research Policy, v. 13, Issue 6, p. 343-373, dez. 1984.

PENROSE, Edith. The theory of the growth of the firm. 2. ed. Oxford: Basil Blackwell, 1959.

PIMENTEL, Fernando. O urgente resgate da competitividade. Valor, São Paulo, p. A14, 14 abr. 2011.

PINTO JR., Helder Queiroz. Estratégias de financiamento. In: KUPFER, David; HASENCLEVER, Lia (Orgs.). Economia industrial. Rio de Janeiro: Campus, 2002.

PORTER, Michael. Vantagem competitiva: criando e sustentando um desempenho superior. Trad. de Elizabeth Maria de Pinho Braga. Rio de Janeiro: Campus, 1989.

1993.

A Vantagem Competitiva das Nações. Trad. de Waltensir Dutra. Rio de Janeiro: Campus,

. Competição = On Competition. Trad. de Afonso Celso da Cunha Serra. 2. ed. rev. e ampl. Rio de Janeiro: Elsevier, 2009.

POSSAS, Sílvia. Economia \& planejamento. In: PELAEZ, Victor; SZMRECSÁRYI, Tamás (Org.). Economia da inovação tecnológica. São Paulo: Hucitec, 2006.

Economia \& planejamento. In: PELAEZ, Victor; SZMRECSÁRYI, Tamás (Orgs.). Concorrência e competitividade: notas sobre estratégia e dinâmica seletiva na economia capitalista. São Paulo: Hucitec, 1999.

PROCHNIK, Vitor. Estudo da competitividade de cadeias integradas no Brasil: impactos das zonas de livre comércio - nota técnica final - cadeia: têxtil e confecções. Campinas, SP: Unicamp-IE-NEIT, 2002.

RANGEL, Armênio de Souza. Uma agenda de competitividade para a indústria paulista. São Paulo: Instituto de Pesquisas Tecnológicas do Estado de São Paulo (IPT), fev. 2008.

REICHEL, Heloísa Jochims. A indústria têxtil do Rio Grande do Sul - 1910 a 1930. Porto Alegre: IML - Mercado Aberto, 1978.

SCHERER, André Luis Forti; CAMPOS, Sílvia Horst. A competitividade da cadeia produtiva têxtil - vestuário do Rio Grande do Sul. Porto Alegre: FEE, 1995.

SERVIÇO NACIONAL DA INDÚSTRIA (Senai); CENTRO DE TECNOLOGIA DA INDÚSTRIA QUÍMICA E TÊXTIL (Cetiqt); INSTITUTO DE PROSPECÇÃO TECNOLÓGICA E MERCADOLÓGICA (IPTM). China: a competitividade da indústria têxtil e o setor de confeccionados. Rio de Janeiro: Senai/Cetiqt, 2004.

SEYOUM, Belay. Trade liberalization and patterns of strategic adjustment in the US textiles and clothing industry. International Business Review, USA, v. 16, p. 109-135, 2007.

STIGLITZ, Joseph E. On the irrelevance of corporate financial policy. The American Economic Review, v. 64, p. 851-866, dec. 1974.

TEXTILE WORLD. Asian fiber consumption update. Disponível em: <http://www.textileworld. com>. Acesso em: 22 maio 2011.

TEXTÍLIA. História da indústria têxtil no Brasil. São Paulo: Textília Net. Disponível em: <http:// www.textilia.net/sitenovo/news_principal_detalhe.asp?PLC_map_001_c=050102\&PLC_cng_ ukey=STAR_STAR_0ST0Y18XF\&PLI_page=2>. Acesso em: 11 mar. 2010.

Teoria e Evidência Econômica - Ano 19, n. 40, p. 9-44, jan./jun. 2013 
UNITED NATIONS STATISTICS DIVISION (Comtrade). Disponível em: <http://comtrade. un.org/db/>. Acesso em: 03 maio 2011.

VERMULM, Roberto. Estrutura industrial brasileira. In: COSTA, Carlos Aníbal Nogueira; ARRUDA, Carlos Alberto (Orgs.). Em busca do futuro: a competitividade no Brasil. Rio de Janeiro: Campus, 1999.

WOHN, Alice. Towards. Gatt integration: circumventing quantitative restrictions on textiles and apparel trade under the multi-fiber arrangement. Journal of International Economic Law, v. 22, Issue 2, p. 1-45, Summer 2001. 